Mitteilungen der Österreichischen Geographischen Gesellschaft,

151. Jg. (Jahresband), Wien 2009, S. 241-276

\title{
Romania's Airlines and Airports during Transition with Particular Reference to the West Region
}

\author{
Remus CREŢAn, Timişoara, David TuRnOCK, Leicester, \\ and Maarten WASSING, Utrecht*
}

with 1 Fig. and 7 Tab. in the text

\section{CONTENTS}

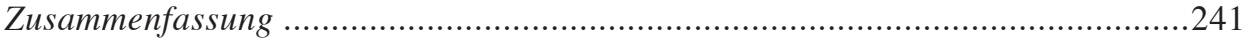

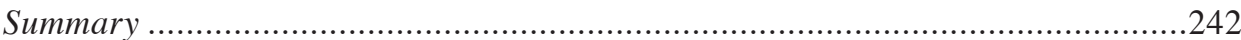

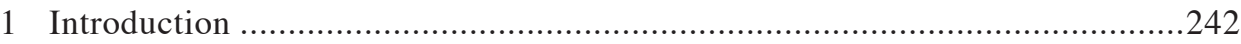

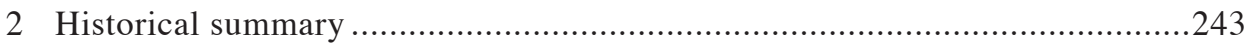

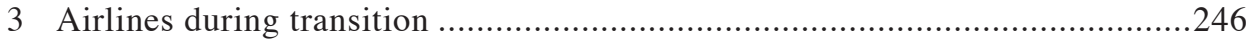

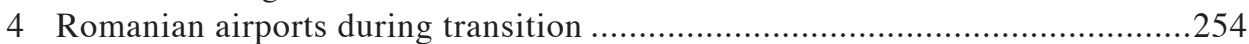

5 The case of the West Region and its cross-border relations............................266

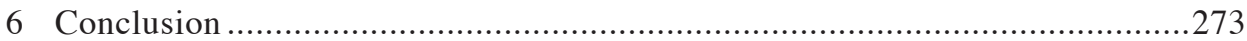

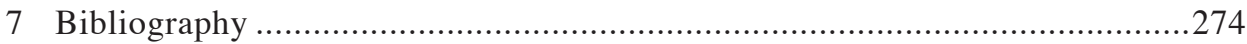

\section{Zusammenfassung}

Die Fluggesellschaften und Flughäfen Rumäniens unter besonderer Berücksichtigung der Westregion

Der Flugverkehr war in den letzten Jahren eine der dynamischesten Branchen der rumänischen Wirtschaft. Nach langsamen Fortschritten in den 1990ern mit vielen Jahren negativen Wachstums haben die Jahre relativer Prosperität im Vorlauf des EU-Beitritts 2007 und das Angebot an Spartarifen durch Low-cost Airlines die Passagierzahlen in die Höhe getrieben.

Der Artikel bietet zunächst eine Einführung in die rumänische Luftfahrt und setzt mit einem Überblick über die Entwicklung von Fluggesellschaften und Flughäfen fort. Rumänien hat beachtliche Erfolge beim Aufbau erfolgreicher privater Fluggesellschaften

\footnotetext{
* Remus CReŢAn, Prof. PhD., Department of Geography, West University, Str. V. Pârvan, RO-200233 Timişoara, Romania; e-mail: cretan_remus@yahoo.com, http://www.cbg.uvt.ro; David TuRNOcK, Prof. PhD., Department of Geography, University of Leicester, University Road, Leicester LE1 7RH, U.K.; e-mail: dt8@leicester.ac.uk, http://www.le.ac.uk; Maarten WAssing, Faculty of Geosciences, Utrecht University, Heidelberglaan 2, NL-3508 TC Utrecht, The Netherlands; e-mail: mawassing@ hotmail.com, http://www. uu.nl
} 
zu verzeichnen (e.g. Blue Air, Carpatair), und führende Regionalflughäfen gleichen in ihrer Dynamik den Flughäfen der Hauptstadt Bukarest in Bezug auf Passagierzahlen und den Ausbau von Einrichtungen.

Die Regionalflughäfen entwickeln sich jedoch unterschiedlich, was auf die Intensität des Wettbewerbs in Regionen mit mehreren Flughäfen zurückzuführen ist. Da weitere Flughäfen in diesen Wettbewerb eintreten werden, wird sich dieser wohl noch verschärfen. Der Beitrag untersucht diesbezüglich die Situation in der rumänischen Westregion und zeigt, dass der Wettbewerb dort im grenzüberschreitenden Zusammenhang gesehen werden muss. Er geht auf Einrichtungen in Ungarn und Serbien ein, deren Hauptstädte der Westregion näher liegen als die eigene Hauptstadt Bukarest.

\section{Summary}

Air transport has been one of the most dynamic branches of the Romanian economy in recent years. After slow progress in the 1990s when there were many years of negative economic growth, the years of relative prosperity in the run-up to EU accession in 2007 have boosted passenger numbers, along with the availability of economy fares linked with the rise of low-cost airlines.

The paper provides first an introduction to Romanian aviation and proceeds with a review of developments for both airlines and airports. Romania has been scoring notable successes with the rise of successful private companies (e.g. Blue Air and Carpatair), while the leading regional airports are fully matching the dynamism of Bucharest in terms of passenger numbers and improved facilities.

However, the performance of the regional airports is uneven due to the intensity of competition within 'multi-airport regions' which seems likely to intensify in future as new airports come on stream. The paper examines the situation in the Romanian West Region and demonstrates that competition must be seen in a cross-border context there; taking note of facilities in both Hungary and Serbia, where the respective capitals are much closer to the West Region than the Romanian capital Bucharest.

\section{Introduction}

Air transport in Romania has been developing rapidly in recent years and is one of the greatest successes of the transition process. There has been very significant growth during the last few years which coincides with accession to the EU (with its deregulated regime for the industry) and the arrival of the budget airlines. We therefore attempt a review that covers both airlines and airports, prefaced by a summary of Romanian aviation development pre-1990.

The state airline (Tarom) has not yet been privatised, but it has modernised and retains a large share of the market for travel to European and Middle Eastern destina- 
tions alongside other former flag carriers. At the same time, the performance of new private companies is examined to show a very broad range of experience extending into the preent low-cost era.

In the case of the airports we have set out to research the performances of the Bucharest [Bucureşti] airports (Băneasa and Henri Coandă), but also the provincial sector which is very important - in terms of both passengers and freight - for the progress of the country's emerging regional centres. For this particular domain we not only draw on official statistical information, but provide a conceptual base linked with specialist literature. And in the case of the West Region and the 'multi-airport' status of its core area (Arad/Timişoara) we consider the evolving dynamics on the basis of consultations with local economic and political agents. Furthermore we adopt a cross-border perspective extending to facilities in both Hungary and Serbia which seem likely to generate stronger competition in the future.

\section{Historical summary}

\subsection{Early twentieth century}

Romania features prominently in the early years of aviation. Although the first real involvement for Bucharest was perhaps the arrival of the French pioneer Louis BLÉRIOT at Băneasa (on the northern edge of the city) in 1909 - where a flying school opened three years later - the Romanian Traian VuiA actually flew a plane three years earlier. Moreover, both Henri COANDĂ and Aurel Vlaicu developed aircraft of their own in 1910 (including the first jet engine in COANDĂ's case).

Following legislation in 1920 providing for the establishment of airline companies, the diplomat Nicolae Titulescu was active in the establishment of 'Compania FrancoRomână de Navigaţie Aeriană' (CFRNA); though it was entirely French-owned by 1925 (renamed SIDNA) and was absorbed into Air France in 1933. The intention was to start operations between Paris and Istanbul [İstanbul], using French Potez aircraft in competition with the prestigious 'Orient Express' railway train. But the flying time from Bucharest to Paris alone was 16 hours and overnight flying between Bucharest and Belgrade [Beograd] (Pančevo) - the world's first night flight (1923) - was essential to offer a worthwhile advantage in the early days.

A new start was then made in 1924 with 'Compania Naţională de Transporturi Aeriene' in 1924. The first regular domestic service started between Bucharest and Galaţi the following year which was later extended to Iaşi. Then a wider range of domestic flights (introduced by 1930) linked the capital with Arad via Sibiu, Cernăuţi [Černìvci] via Galați; and Halmeu (near Satu Mare) via Sibiu and Cluj [Cluj-Napoca] (en route to Prague [Praha] and Strasbourg). Additionally, Oradea could be reached either via Cluj or by Turnu Severin, Timişoara and Arad. There were also routes between provincial cities, e.g. Cluj - Galaţi with onward flights to Cetatea Albă [Bìlgorod Dnìstrovs'kij] and Constanţa; also Arad to Cluj and Cernăuţi and Cluj to Satu Mare. 
Other international flights operating from Bucharest in the 1930s included: Belgrade - Zagreb - Venice [Venezia] - Milan [Milano]; Arad/Oradea - Budapest -Vienna [Wien] - Berlin; Cernăuţi - Lwów [L'vìv]; Sofia [Sofija] - Istanbul, Salonica [Thessalonikī] - Athens [Athēnai] and Warsaw [Warszawa] - Gdańsk - Copenhagen [København]. These involved various foreign companies: Air France flew to Romania from 1930; ČSA (Czechoslovakia) from 1933, with flights from Bucharest to Prague via Cluj; Aeroflot from 1935, flying Avia-Fokker planes from Moscow [Moskva] to Prague via Cluj; Ala Littoria (Italy) and Deutsche Lufthansa (Germany) from 1937; and PLL (Poland) from 1938.

However, a domestic company LARES (Liniile Aeriene Român Exploatate de Stat) started in 1930 and then merged in 1937 with a private company (with some foreign capital) - 'Societatea Anonimă Română de Transport Aerian' (SARTA) - in 1937. Passenger numbers rose from just 65 in 1925 to 15,430 in 1939 (MinĂILESCU 1971, p. 62).

As regards the airports, Băneasa was the leading facility: dating to 1920 and acquiring its own maintenance facilities in 1923 (becoming the basis of the Romaero aircraft company in the 1960s). It was eventually endowed with a $800 \mathrm{~m}$ concrete runway. There was also a second 'aerodrome' a little further north of the city at Otopeni. Facilities in the provinces emerged early at Arad - mentioned as an overnight stopping point ('escală de noapte') on the Bucharest - Belgrade route, while dates are available for Cluj and Suceava (both 1932), Timişoara (1935), Satu Mare (1936) - receiving flights from Cluj which all called at Oradea - and Craiova (1938) when strategic considerations were uppermost. Other aerodromes are mentioned at Balcic [Balčik] (today in Bulgaria), Caransebeş, Cernăuţi, Chişinău, Constanţa, Galaţi and Oradea; as well as more basic airfields at Arad, Baia Mare, Braşov, Cetatea Albă, Deva, Iaşi, Petroşani, Sibiu and Târgu Mureş. These facilities were of course very important during the Second World War, e.g. Cluj - used by the Hungarian military and also by the Luftwaffe - was a key installation completely destroyed in the final phase of the war; while Otopeni was also of the greatest importance to the Axis.

Meanwhile Romania also contributed to the development of aircraft; most notably through IAR at Ghimbav, Braşov, where military aircraft were built before and during the Second World War.

\subsection{The Communist period}

Aviation recovered after the war with Soviet involvement in a joint company established in 1945: 'Transporturile Aeriene Româno-Sovietice' (TARS). A significant achievement was the reconstruction of Băneasa (following German bombing after Romania's 1944 coup) with a distinctive terminal building - a central dome with three wings (representing a propeller with three blades). This was an important architectural structure in its own right and was not finished until 1952. A Bucharest - Prague service started in 1946, followed by flights to Budapest, Sofia and Warsaw during 1946-1947.

TARS became a purely Romanian company (Tarom) in 1954 under the 'new course' after STALIN's death (when the Soviet share was purchased). There were now routes to 
Berlin and Moscow in collaboration with Lufthansa and Aeroflot, respectively. And as the network evolved routes remained largely European, but they also extended to the Middle East (e.g. Cairo [Al Kahira] from 1958) and North Africa as well as North America, China and North Korea: the first flight across the Atlantic was made in 1966 and there were regular flights into New York (JFK) in 1974. The Tarom fleet was dominated by Soviet aircraft although the BAC 1-11 (built in Romania as the ROMBAC) was introduced in 1983.

The new Băneasa airport had an effective runway of 1,950 m (though actually 2,200 m), requiring diversion of the Pipera-Tunari road, while hangars were built during 1972-1974. However, passenger numbers rose from 24,000 in 1948 to 405,000 in 1965 (exceeding a nominal capacity of 300,000) and 789,000 in 1969 by which time some foreign companies had to be refused access (MiHĂILESCU 1971, p. 62). Expansion was difficult because of the proximity of the Ploieşti road and so the decision was taken to develop a new airport $16 \mathrm{kms}$ north of the city. Since most flights came from the north this strategy ensured that large aircraft could most easily be kept away from the city core. Moreover, a military facility (used occasionally by Tarom) was already in existence at Otopeni and so the need for additional agricultural land was limited largely to a runway extension to 3,600 m. Work started at Otopeni in 1964 and the airport was fully open in 1970 (hangars in 1975) with an annual capacity of 1.2 million passengers. Meanwhile Băneasa was reserved for domestic traffic.

Airport development for internal flights took place around the country from 1946. For example, activities including major land drainage were started at Tulcea at this time in order to receive flights by TARS from 1952. Concrete runways $18 \mathrm{~cm}$ thick were laid during 1952-1960 at Arad, Bacău, Constanţa, Craiova and Timişoara (e.g. Craiova in 1952 with a Tarom service starting in 1957); followed by Baia Mare and Cluj in 1966 (with a new terminal at the latter in 1969), Oradea and Suceava in 1967, Târgu Mureş in 1968, Iaşi in 1969, Sibiu in 1970, Tulcea (a new airport south of the town) in 1973, Satu Mare in 1975 and Caransebeş in 1979. Projects were formulated by Institutul de Proiectări Transporturi Auto Navale şi Aeriene and work was carried out mostly by Direcţia Generală a Construcţiilor.

In order to limit disturbance, the airports were built in some distance from the towns they served although this could vary from just five kilometres at Oradea and Sibiu to 13 at Iaşi and Suceava and 26 at Constanţa. Further development was needed at some of the busier airports, e.g. Craiova in 1968 and Bacău in 1971.

Meanwhile, Constanţa (opened in 1961 at Mihail Kogălniceanu village) was extended in 1968 and 1974. Although it was a long way from the city it served, it was initially intended to be a military installation centrally placed within the Dobrudsha [Dobrogea] region between the railway from Medgidia to Tulcea and Tasaul Lake [Lacul Taşaul] on the Black Sea coast. It became a civilian airport in the 1970s when the Black Sea tourist trade was developing.

Meanwhile, facilities at Satu Mare were improved in the context of the Warsaw Pact, given the close connections with Czechoslovakia, Hungary and Poland as well as Soviet territory in Ukraine. 
Timişoara airport at Giarmata gained new buildings and a runway extension $(2,500-3,500 \mathrm{~m})$ when it became the country's third international airport in 1980. There were also a number of relocations: at Baia Mare from Recea to Tăuţii-Măgherăuş due to sandy soil; while the small facility at Suceava provided in 1960 (without a paved runway until 1963) was replaced in 1967 as the tourist industry developed. Meanwhile, at Târgu Mureş the airport moved from cramped conditions beside chemical and sugar factories at Mureşeni to a more spacious site close to the railway at Vidrasău.

In 1980 all internal flights operated between Bucharest and major provincial cities, with Arad, Cluj-Napoca, Constanţa, Oradea, Sibiu and Timişoara as the busiest routes. Other towns included in the network were Bacău, Baia Mare, Iaşi, Satu Mare, Suceava and Tulcea, with relatively small numbers of passengers at Caransebeş (for Reşiţa) and Craiova. Seasonal routes were offered to Constanţa from Bacău, ClujNapoca and Timişoara.

Airport development was significant, especially for the county towns furthest from Bucharest. Allowing for Tarom bus connections from Bacău to Piatra Neamţ, Caransebeş to Reşiţa, Sibiu to Alba Iulia, Suceava to Botoşani and Târgu Mureş to Bistriţa (and the resort of Sovata), the only such towns more than $200 \mathrm{kms}$ from Bucharest (straight line distance) without an air connection were Deva, Miercurea Ciuc, Turnu Severin, Vaslui and Zalău (Rusta \& Bugă 1984, p. 445).

However, domestic traffic remained modest at 4,900 flights in 1955 rising to 8,000 in 1977, while international flights increased from 1,300 to 110,000 during the same period. Passenger numbers rose steadily from 12,000 in 1938 , to 39,000 in $1950,118,000$ in 1960, 849,000 in 1970, 1.87 millions in 1980, 2.74 millions in 1990 (but only 1.86 in 1995 and 2.36 in 2000). Freight increased but remained relatively insignificant at $1,000 \mathrm{t}$ in 1950 , rising to 5,600 in $1960,11,300$ in $1970,22,400$ in 1980 and 37,000 in 1990 before falling to 16,100 in 2000 (5.3 out and 10.8 in).

Meanwhile, Romania rebuilt its plane-making industry from the 1960s with further IAR production while the ROMBAC was built by Romaero (under a British Aircraft Corporation licence) as already noted.

\section{Airlines during transition}

Romania's transition to a market economy offers great potential for air transport while the EU accession process ensures that the process will now be competitive. However, although one of the aims of the Treaty of Rome (1957) was to stimulate competition in transport, as in other economic sectors (DEMPSEY 2004, pp. 1-10) aviation was excluded until the introduction of a Single Internal Market in 1992. Hence, competition was relatively benign or non-existant, since close relations between governments and national aviation companies reflected the latter's importance for national security - with the Conference of Paris according sovereign rights to each state in respect of its airspace (GRAHAM 1995, p. 46). 
But all this changed when three 'Packages of Deregulation Measures' were adopted during 1987-1992 to create a competitive market. All restrictions were removed by 1997 under the 'Open Sky' agreement which allowed European airlines to operate on any route between the airports in the region; so that all flights (including internal flights) were opened to international competition over fares, service frequency and capacity (Burghouwt 2005, pp. 45-47). At the same time, the EU placed stringent controls on the support given by national governments to traditional 'flag carriers' (FRUHLING 2006). These companies reorganised to cope with competition that quickly included the appearance of low cost airlines (KANGIS \& O'ReILly 2003). Of course, before EU accession in 2007 Romania's state airline retained its privileged position and foreign airlines had to negotiate access; while the domestic market was also protected. But now the competitive regime is starting to take effect.

\subsection{Romania's state airline: Tarom}

In 1990, Tarom was typical of state airlines in transition through its ageing fleet of Soviet aircraft and inherited a proportion of non-viable 'political' destinations in its flight schedule. There was also the formidable challenge of restructuring on the basis of profitability.

Tarom was slightly different, however, in already finding a significant part of its business in Western Europe and North America. Moreover, it had good links with UK planemakers and included BAC 1-11 aircraft in its fleet.

Nevertheless, Tarom was forced to reduce its programme and concentrate on the most profitable routes: long-haul flights largely ceased in favour of a predominantly regional role. Fleet modernisation concentrated on Boeing aircraft, although three Airbus 310 s were acquired in the late 1990s (with one subsequently lost in a crash) and four 100-seat Airbus 318s arrived in 2004-2005.

Indeed, recent Tarom investment has been dominated by the purchase of these aircraft which have all now been delivered. Meanwhile, Soviet aircraft with heavy fuel consumption were gradually withdrawn. The process was completed in 1998, when the Antonov 24 fleet was eliminated from domestic services with the prospect of replacement by seven 42-500 planes from ATR (Aero International Regional, acting for British Aerospace, Aerospatiale and Alenia of Italy). It seems that these planes were first sought for delivery by 2000 for use on regional and domestic routes, following enquiries regarding the Fokker Saab 2000 (carrying 58 passengers at $675 \mathrm{~km} / \mathrm{h}$ ) and the Dornier-328. But evidently only two were acquired initially (with their use reported on thrice-weekly services from Cluj-Napoca to Vienna in 2000). They were followed by a $€ 40$ million financing contract for fleet rehabilitation concluded in 2000 between the government, the European Investment Bank and Tarom in respect of five ATR 42-500s with Pratt \& Whitney engines.

Tarom now had the aircraft to re-enter the domestic market in 2004 when Angel went bankrupt. With a fleet of seven ATRs, Tarom offered $€ 10$ single fares during the winter of 2004-2005 from Bucharest to Arad, Bacău, Baia Mare, Oradea, Satu Mare, Sibiu, Suceava and Târgu Mureş. Tarom now has $75 \%$ of domestic market and 
rising numbers $(250,000$ in the first half of 2008 after 160,000 a year earlier). Its only serious rival is Carpatair (with a $25 \%$ share generated on routes that are broadly complementary to Tarom's activities) since other players like Blue Air and Wizz Air do not have the fleets of small planes needed to offer two daily flights on domestic routes.

Owned $92.6 \%$ by the Ministry of Transport, the company was first prepared for privatisation in 1997, leading to an updated programme (in 1998) for restructuring to reduce employment, eliminate uneconomic routes and rationalise the fleet. Tarom then became one of the 64 companies in the PSAL programme negotiated with the World Bank in 2000 and it was hoped that $25-40 \%$ of stock might be sold in 2000, on the strength of a positive balance sheet, high class service and a modern fleet. But the business community was not convinced that the strategy was sustainable, because Romania has not yet signed up to the Open Skies Agreement. Therefore government bilateral agreements still determined who flew in and out.

Some drastic changes had to be made at this time. After Tarom's initiative of 1998 using Airbus 310s on routes from Bucharest to New York, Chicago, Montreal [Montréal] via Satu Mare, the decision was made in 2004 to cancel all long haul flights including the service to Beijing. Hence there was the prospect of a $\$ 3.0$ million profit in 2005 (the first since 1990) as a possible basis for privatisation in 2005/06. However this event is still awaited. In the meantime Tarom joined 'Sky Team' which includes Air France-KLM, Aeroflot, Alitalia, Delta, Czech Airlines, China Southern and AeroMexico.

\subsection{New Romanian airlines}

The end of the Tarom monopoly meant that new airlines could start from scratch without the legacy of dependence on heavy fuel-consuming Soviet aircraft. Typically, they used western aircraft in niche markets that included some longer-range flights, e.g. serving Romanian expatriate communities in South America, also Australia and Canada, in contrast to Tarom's increasingly short- and medium-range activities.

Owned by the National Defence Ministry, Romavia was established in 1991 by the Romanian government for VIP state and ministerial flights. But although it also operates charter and scheduled passenger/cargo services to Austria (Vienna), Israel (Tel Aviv) and Italy (Perugia and Rome [Roma]-Ciampino). It has a Boeing 707 (for the president), two British Aerospace 146s, two ROMBAC 1-11s, an Antonov 26 and three Dauphins.

Acvila Air was founded in 1993 by Ion Menciu who remains the sole owner. The intention was to use former Soviet aircraft - Ilyushin 76s as well as Antonovs (12s, $24 \mathrm{~s}$ and 124s) - on cargo charters operating to Italy, Portugal and Spain as well as Egypt and the United Arab Emirates. The company then used its experience to enter the passenger charter business in 2004 using 142-seat Macdonnell-Douglas aircraft. It also flies to Ukraine in cooperation with Air Ukraine. It now operates a Boeing 737, two Airbus 320s, two British Aerospace 146s as well as a single Antonov and a Tupolev 154. In 2004, Acvila Air was taken over by a new company Jetran Air using a fleet of twelve McDonnell Douglas planes and one Fairchild Dornier to reach holiday destinations from Băneasa and Otopeni. 
Ion Tiriac Air started in 1998 in Bucharest as a business aviation concern operating one flight daily on average. This involved competition in the charter market (especially to Budapest and Vienna - but also Milan, Moscow, Nice and Paris) with Carpatair, Romavia and Tarom. The company has two nine-seat Gulfstream 200s; one 44-seat Boeing 737-300, one 13-seat Bombardier Global 5000; a four-seat Eclipse 500 , an Antonov 26 and a Cessna 560V as well as two helicoptersa (a four-seat Bell 206 and a six-seat Augusta 109).

Carpatair was started in Bucharest in 1999 by Nicolae Petrov (a pilot with business and legal backing) to exploit a regional niche market, starting with a route to Treviso. But the company moved to Timişoara - selected for its infrastructure and regional hub potential - and there are now twelve Saab aircraft (six 340s and six 2000s) operating domestic flights from the Timişoara hub to Bucharest and Iaşi by 2005; Satu Mare, Oradea and Suceava in 2006; Craiova, Târgu Mureş and Constanţa in 2007; and Bacău, Cluj-Napoca and Sibiu in 2008 (when they planned to double the total number of internal flights).

Meanwhile, Carpatair's foreign destinations were Frankfurt [Frankfurt am Main] and Paris in 2006; Athens and Bari in 2007; followed by Odessa [Odesa] and Salonica in 2008. Their programme now includes a further range of destinations involving Germany (Düsseldorf, Munich [München] and Frankfurt), Hungary (Budapest), Italy (Ancona, Bergamo, Bologna, Florence [Firenze], Naples [Napoli], Rome [Roma], Treviso, Torino and Verona - some on a charter basis) and Moldova (Chişinău). Passenger numbers grew to 100,000 in 2002 and 365,000 in 2008 .

Carpatair is thus a fine example of a regional airline that has developed a conventional radial network usually typical of flag carriers (BuRGHOuwT et al. 2003). And this is well organised around the Timişoara hub to collect passengers from cities in Romania (Bacău, Bucharest, Cluj-Napoca, Craiova, Iaşi, Oradea and Suceava) and adjacent states (Chişinău, Kiev [Kiïv], L'vìv and Odessa) for transfer to flights reaching West European cities in the late morning. The process is then reversed later in the day following a routine mentioned in the section on Timişoara airport below (WASsING 2008).

Another major player is Blue Air, owned by Nelu IORDACHE, which started in 2004 with two Boeing 737s (a third was acquired in 2005) offering low-cost return flights from Băneasa to Barcelona, Lyon, and Milan-Bergamo for $€ 19$. Although the company gained an unfortunate reputation for delayed flights (especially among the 'cherry pickers' in Barcelona) it has established itself well. In 2006, it was the leader of the low-cost market in Romania ( 0.4 million passengers) with 50 flights each week in summer. The number increased to 75 in 2007, when new services started to London (Stansted) and Stuttgart, while the acquisition of Aegean Airways (Greece) seemed a possibility. They were still the low-cost leader at the end of 2008, despite scaling down growth due to competition from their main rival Wizz Air, as well as Germanwings and Easy Jet. Even so flights are to increase $80-100 /$ week with new destinations. The programme now covers Belgium (Brussels [Bruxelles/Brussel], France (Lyon and Paris), Germany (Berlin, Köln/Bonn and Stuttgart), Greece (Salonica), Italy (Bologna, Catania, Rome, Torino and Verona), Portugal (Lisbon [Lisboa]), Spain (Barcelona, Madrid, Valencia and Malaga) and the United Kingdom (London). And although Bucharest - Arad is the only internal service there are European flights that call at Arad (Valencia and 
Verona), Bacău (Milan-Bergamo, Rome and Torino) and Sibiu (Köln/Bonn, Madrid and Stuttgart). Moreover the summer programme has some flights starting from these provincial airports as well as a Constanţa - Brussels service. The fleet has grown to five Boeing 737s (plus two BAE aircraft rented) and they intend to acquire three more.

Reference should also be made to Jetran Air which emerged in 2005 as a leasing company operating in conjunction with various airlines in Europe and North Africa. With an elderly fleet of eight aircraft - mainly McDonnell Douglas 'super quiet' MD80s - the company was acquired by the Tender Group in 2008 and is now starting to operate charter flights on its own account from a base in Bucharest. However, some Jetran managers and key workers have started a new company in Bucharest Medallion Air - to operate in leasing and charter work with newer MD 83 aircraft of which two were secured in 2009. And finally the Sibiu businessman Ilie CARABULEA announced his intention in 2008 to diversify from his Atlassib bus company into lowcost air travel through a new company Air Transilvania, although no further details are available as yet.

However, several new airlines failed after a promising start. Jaro International started in 1991 as a charter company based at Băneasa - originally with one Boeing 707, but subsequently with two more 707s (one for cargo); also two BAC 1-11s and one Yakovlev 42. Although Jaro remained basically a charter airline for Germany, Italy and Scandinavia, it started regular flights to London (Gatwick) - with a 160 promotional fare - and Düsseldorf via Timişoara. In 1996 services were extended to Catania and Köln/Bonn. Other destinations were Berlin, Frankfurt, Girona, Hamburg, Hannover, Malta, Palma de Mallorca, Skopje, Stockholm and Vienna, as well as Ostend [Oostende] and Southend for cargo. It flew the Atlantic to JFK in 1991 and started regular flights to Montreal and Toronto in 1997 (continuing until 2000, when the operations were stopped in the face of Tarom competition). The company poached Tarom crew and technicians by offering better conditions but got into trouble in Canada in 1998/99 over unauthorised flights taking lobsters to Belgium and Spain while licensed as a charter operator between Romania and Canada. The company went bankrupt in 2001.

Dac Air started in 1996 as a charter company with a base in Bucharest flying Bombardier (Canada) De Havilland Dash eight-seaters on domestic flights. Starting initially with flights to Timişoara/Oradea, they went on to serve Cluj-Napoca, Constanţa and Iaşi to finish with a total of twelve locations by the end of the year. And such was the effectiveness of their competition that Tarom eventually agreed to transfer to Dac Air all their rights to domestic and regional routes later in the year. Dac Air also obtained four Canadian Regional Jet 200s from Bombardier and placed an initial order for 16 more planes of both types to serve 20 international destinations. These included Bologna (from Bucharest), Budapest (from Timişoara), Istanbul (from Bucharest and Constanţa), Munich (from Timişoara) and Venice (from Bucharest and Timişoara); while a feeder service from Cluj-Napoca to Timişoara gave connections for Budapest, Munich and Venice. Other destinations were Athens, Salonica and the Black Sea coast. However, the company has been defunct since 2006.

Angel Airlines started in 2001 at Băneasa flying British Aerospace Jetstream planes to a range of domestic airports: initially Baia Mare and Iaşi, but subsequently to Arad, Constanţa, Oradea, Satu Mare, Sibiu, Suceava and Târgu Mureş as well (sometimes on 
a codeshare basis with Tarom). But in 2002 activity expanded with the offer of charter flights to Albania, Bulgaria, Greece, Italy and Turkey. In addition, scheduled flights were introduced on international routes from Bucharest to Tirana and from Constanţa to Istanbul (with plans for Bucharest - Craiova - Rimini and an extension from Tirana to Bari). But the company folded due to bankruptcy in 2004. Subsequently, Tarom resumed operations on domestic routes from which it had previously withdrawn in 2001 .

Finally, reference should be made to two other companies which made only a modest impact. Grivco Air was based at Băneasa during 1993-2001 and flew a Yakovlev 40 on various routes, e.g. Sibiu - Satu Mare - Brescia in 2000. And Airom operated briefly during 1999-2000 using an Antonov 24 and a Yakovlev 42 on tourist charters from Băneasa to the Eastern Mediterranean including Athens and Salonica. Unfortunately, since the business could not be extended beyond a short summer season the company withdrew at the end of 2000 .

\subsection{Foreign airlines}

Foreign airlines are mainly the European 'flag-carriers' - Air France, British Airways, Lufthansa, etc. - operating 'classic' flights. Some have been increasing their activities with additional services from regional airports, e.g. Lufthansa fly from Otopeni to Frankfurt and Munich; but also to Munich from Cluj-Napoca and Timişoara. Austrian Airlines have services from Vienna to Baia Mare, Cluj-Napoca, Iaşi and Sibiu as well as Bucharest, while Malév now fly additionally from Budapest to Constanţa, Iaşi and Târgu Mureş and Moldavian Airways serve Timişoara on a codeshare basis with Carpatair.

However, a major impact has been made by the arrival of foreign low-cost operators, coinciding with the opening of the Romanian market for foreign competition.

My Air - which started as Volaire (hoping to fly to Milan and Rome in competition with Tarom) - offer low-cost flights to Milan and Venice. They are poised to double passenger numbers on their Bucharest routes from 220,000 in 2006 to 380,000 in 2008 and hope to develop links with France and Spain starting in 2008 with 90 -seat Bombardier planes with routes to Barcelona, Paris and Valencia.

Another Italian company, Club Air, connected Bucharest, Bacău, Timişoara and Cluj-Napoca with Ancona, Bari, Bologna, Florence and Verona - with Rome as another possibility along with Arad - Köln/Bonn. But it was reported in December 2006 that the Italian authorities had withdrawn flight rights; at the same time as the Spanish authorities withdrew the flight rights of Air Madrid operating between Bucharest and Barcelona (though Clickair later surfaced with the same plan).

Meanwhile, Sky Europe (based in Bratislava with a Boeing 737 fleet) was poised to begin operations in Romania in 2006 seeking to develop a hub at Băneasa. They also planned similar operations not only at Bratislava but also at Budapest, Cracow [Kraków], Prague and Warsaw. Flights to Bratislava (with a Vienna bus connection) from Bucharest and Sofia (priced at $€ 14$ single for the cheapest tickets but $€$ 50-108 return) were to be followed by Budapest and Rome - with five additional destinations under study: Dublin, London, Manchester, Milan and Paris. Close marketing coop- 
eration developed with MyAir (primarily in the Italian market), but talk of a merger proved to be unfounded and the both companies are now bankrupt.

The most substantial challenge has come from Wizz Air (Hungary) who started with a Târgu Mureş - Budapest service in 2006. This was followed in 2007 by services to Barcelona and Rome; also from Arad to Bergamo and from Băneasa to all three original destinations as well as Dortmund and London (Luton). They have now started flights from Bucharest to Liverpool, Parma and Valencia - with extra flights to London and Rome. Wizz Air then started flights from Târgu Mureș to Luton - on top of their eight existing routes from Bucharest and Târgu Mureş. They hoped for 1.0 million passengers in the Romanian sector in 2008 in order to overtake Blue Air. They then relocated in order to develop a big stake in Cluj-Napoca with services to Bucharest, Dortmund, Milan and Valencia. And they are now opening a new base at Timişoara, where the operation and maintenance of three Airbus 320s should generate up to 100 jobs. As already noted, Wizz Air (and Blue Air) don't have the fleets of small planes that are needed to offer two flights daily on domestic routes: Wizz Air operated between Bucharest and Cluj-Napoca but closed during the 2008/09 winter - after less than a year using a large plane.

Ryanair started in Romania in 2008 with Arad - Milan-Bergamo and Constanţa Pisa flights (also Bergamo from the latter in 2009). They avoided relatively expensive airports like Bucharest in preference for places with little competition (only Blue Air at Arad and Malév at Constanţa), though they have already left Arad following a dispute over taxes.

Three other companies should be mentioned. Germanwings - the low cost division of Lufthansa - started operating from Băneasa in 2007 to several European destinations, but they now have a presence at Cluj-Napoca. Wind Jet, based in Catania (Sicily), operate to Forli from Bucharest and Timişoara (also from Bucharest to Catania). And while Easy Jet dropped their Bucharest - London flights due to insufficient demand, new flights from Bucharest to Madrid and Milan started in 2009.

\subsection{Discussion}

Evidently, changes have been quite dramatic recently, with Romania now benefitting from the new competitive regime as Central and Eastern Europe becomes a new pioneer zone for low-cost airlines trying to break out of the overcrowded West European aviation market (DoBruszKes 2009). Such airlines attracted some 2.0 million passengers on Romanian routes in 2007 with $2.5-2.7$ millions anticipated in 2008. This would equate with $50 \%$ of established airlines volume (including domestic flights) and constitutes an impressive performance after their first beginnings in 2004.

Clearly, the top two companies are Blue Air and Wizz Air with around 1.0 million passengers each in 2008 (only about 20,000 difference), though their passenger numbers were 0.8 and 0.5 millions respectively in 2007. While Blue Air hoped for much greater expansion to 1.6 millions in 2008 , Wizz Air is clearly growing more rapidly and expects to double to 2.0 millions in 2009 with new flights - and so gain the lead for business with Romania - while Blue Air will be hard pressed to keep pace. My 
Air carried 0.32 million passengers during the first three quarters of 2008, but there was some speculation over expansion linked with collaboration with Sky Europe, although this has now collapsed.

It is interesting to see that the low-cost airlines use different airports in order to limit competition: Blue Air fly from Arad, Bacău and Bucharest; My Air from Bucharest and Timişoara; Ryanair (formerly) from Arad and Constanţa; and Wizz Air from Băneasa and Timişoara.

They are all keen to offer special deals at holiday times, e.g. Christmas with fares as low as $€ 30$ (including airport taxes) in 2008. Most of opportunities were offered in Bucharest to passengers for Barcelona, Bari, Bologna, Brussels, Catania, Milan, Naples, Paris, Rome and Venice by My Air; and also to Barcelona, Dortmund, Liverpool, London, Milan, Parma, Rome and Venice by Wizz Air; as well as Barcelona, Madrid and Valencia by Blue Air; London, Madrid, Milan by Easy Jet; and Vienna by Sky Europe. From the provinces there were deals from Cluj-Napoca to Barcelona, Budapest and Rome by Wizz Air, from Arad to Valencia by Blue Air; and from Timişoara to Vienna by Sky Europe (though this route has now been abandoned).

The low-cost airlines are also competing very effectively with bus services, already affected by rising fuel costs. The Eurolines company has had to cut back on its services to Italy and Spain due to falling profits and is concentrating more on Budapest, Prague and Sofia.

Meanwhile, the regular airlines still have a far greater share with over 6.0 million passengers in 2008, although they are being forced to keep their fares competitive. Competition for Tarom on domestic flights is limited by the lack of small aircraft that are needed to cope with low airport capacity. Thus, Blue Air dropped their idea for a Bucharest - Cluj-Napoca service, since they didn't have small aircraft, though they remain interested in the route. Carpatair flights are basically complementary since they serve the Timişoara hub and do not offer services between Bucharest and the provinces.

However, Tarom faces growing competition as European airlines start flying to provincial airports. Thus, passengers from Western Europe may reach a range of provincial cities relatively quickly by changing to Austrian Airlines, Lufthansa or Malév flights in Vienna, Munich and Budapest, respectively, as alternatives to taking Tarom flights via Bucharest. Tarom prices tend to be lower, but with Bucharest located in the southeast of the country (making for longer total distances) and waiting times of several hours in transit the competition can usually offer much shorter journeys which appeal to business passengers - on top of the attraction of day return trips on which Carpatair specialise so successfully for Romanian businessmen travelling in the opposite direction.

More services from Western Europe to Romanian provincial destinations may be anticipated, e.g. Air France/KLM are considering Cluj-Napoca - Paris and Bucharest - Lyon services in conjunction with Tarom. Finally, reference may be made to charter flights. Figures from the National Association of Travel Agents show there were 1,800 charter flights in 2007 worth $€ 8.3$ millions (handling about half of all summer tourism air traffic) with Carpatair (670) in first place - as a company which concentrates heavily on this business - followed by Tarom with 650 and Tiriac Air with 450. 


\section{Romanian airports during transition}

Romania is well-endowed with civilian airports, although many have only short unpaved runways and few can accommodate wide-bodied aircraft (see Table 1).

\begin{tabular}{|l|c|c|c|}
\hline Runway (in m) & Paved & Unpaved & Total \\
\hline Over 3047 & 3 & Nil & 3 \\
\hline $2438-3047$ & 9 & Nil & 9 \\
\hline $1524-2437$ & 12 & 2 & 14 \\
\hline $914-1523$ & 1 & 12 & 13 \\
\hline Below 914 & Nil & 22 & 22 \\
\hline Total & $\mathbf{2 5}$ & $\mathbf{3 6}$ & $\mathbf{6 1}$ \\
\hline
\end{tabular}

Source: http://www.flagcounter.com/factbook/ro

Table 1: Civil airports in Romania

Moreover, business has been quite modest as can be seen from official figures on passenger transport (see Table 2) which show a declining trend from 1990 to 2005 with a revival occurring only recently. There has been a continuing decline in rail travel, while road passenger transport revived after 2000 and air transport after 2005 with the latter's share of the total fairly stable at around a tenth. However, the figures are based on the domestic front and full extent of the boom since 2005 is not properly expressed.

\begin{tabular}{|l|r|c|r|r|r|r|r|r|r|r|}
\hline Mode & \multicolumn{2}{|c|}{1990} & \multicolumn{2}{c|}{1995} & \multicolumn{2}{c|}{2000} & \multicolumn{2}{c|}{2005} & \multicolumn{2}{|c|}{2007} \\
\hline & $\mathrm{p} / \mathrm{kms}$ & \multicolumn{1}{c}{$\mathrm{pc}$} & $\mathrm{p} / \mathrm{kms}$ & \multicolumn{1}{c}{$\mathrm{pc}$} & $\mathrm{p} / \mathrm{kms}$ & \multicolumn{1}{c|}{$\mathrm{pc}$} & $\mathrm{p} / \mathrm{kms}$ & \multicolumn{1}{c|}{$\mathrm{pc}$} & $\mathrm{p} / \mathrm{kms}$ & \multicolumn{1}{c|}{$\mathrm{pc}$} \\
\hline Rail & 30,582 & 52.7 & 18,879 & 54.5 & 11,632 & 54.0 & 7,985 & 36.4 & 7,722 & 34.8 \\
\hline Road & 24,007 & 41.3 & 12,343 & 35.6 & 7,700 & 35.7 & 11,812 & 53.9 & 12,322 & 55.5 \\
\hline River & 58 & 0.1 & 24 & 0.1 & 15 & 0.1 & 24 & 0.1 & 26 & 0.1 \\
\hline Air & 3,418 & 5.9 & 3,415 & 9.9 & 2,212 & 10.3 & 2,093 & 9.6 & 2,123 & 9.6 \\
\hline Total & $\mathbf{5 8 , 0 6 5}$ & $\mathbf{1 0 0 . 0}$ & $\mathbf{3 4 , 6 6 1}$ & $\mathbf{1 0 0 . 0}$ & $\mathbf{2 1 , 5 5 9}$ & $\mathbf{1 0 0 . 0}$ & $\mathbf{2 1 , 9 1 4}$ & $\mathbf{1 0 0 . 0}$ & $\mathbf{2 2 , 1 9 3}$ & $\mathbf{1 0 0 . 0}$ \\
\hline
\end{tabular}

Source: Anuarul Statistic for the relevant years

Table 2: Passenger transport in Romania 1990-2007; the passenger-kilometer figures are in millions

Passenger traffic has risen by some ten percent annually since 1998, helped additionally by rising disposable income plus the stimulus of low-cost flights. Passenger numbers increased from 2.36 to 4.19 millions during 2000-2005 (2.09-3.73 millions for international travel and $0.27-0.49$ millions for domestic travel), while flight movements grew from 59,500 to 105,800 . 
Cargo and postal traffic has been much less dynamic falling from 83,000 $\mathrm{t}$ in 2000 to $16,800 \mathrm{t}$ in 2002 , when Tarom's financial difficulties meant there was insufficient capacity available - pending the acquisition of more aircraft - although there was a slight recovery to $21,300 \mathrm{t}$ in 2005 .

Certainly, air passenger traffic has grown much faster than GDP in recent years. During 2004-2005 the GDP growth rate was 6.2\% per annum on average, while air passengers increased by $13.4 \%$. Then, during 2006-2007, when the GDP growth rate averaged $6.6 \%$, the growth in air passengers was $37.5 \%$ (coinciding with the development of the low-cost services) (EUROSTAT 2006).

Nevertheless, compared with other countries the use of air transport is still low. Taking the seven EU member states in East Central Europe (excluding the Baltic States), Romania scored just 311 flights per 1,000 inhabitants in 2007 - the lowest. The next lowest being Slovakia (409), while the highest was the Czech Republic with 1282 (see Table 3).

\begin{tabular}{|l|c|c|c|}
\hline Country & Flights th. & Popn.mn. & Flights/th.pop \\
\hline Bulgaria & 6,071 & 7.26 & 836 \\
\hline Czech Republic & 13,098 & 10.22 & 1,282 \\
\hline Hungary & 8,580 & 9.93 & 864 \\
\hline Poland & 17,120 & 38.50 & 443 \\
\hline Romania & 6,909 & 22.22 & 310 \\
\hline Slovenia & 1,504 & 2.01 & 748 \\
\hline Slovakia & 2,232 & 5.46 & 409 \\
\hline Total & $\mathbf{5 5 , 5 1 4}$ & $\mathbf{9 5 . 6 0}$ & $\mathbf{5 8 1}$ \\
\hline
\end{tabular}

Source: EUROSTAT

Table 3: Air flights in East Central European EU member states 2007

Facilities have been improving to accommodate further growth which has been explosive during the EU accession process (following the experience of Hungary and Poland). This can be seen across Central and Eastern Europe generally and also in Romania (see Fig. 1). And there are good long-term prospects in connection with business and tourism.

Romanian airports have traditionally been state-owned, but the trend since 1989 has been towards devolution (to local authorities in 1998) and now towards privatisation. Since 1998 only the four most important airports (all with runways that are able to accommodate wide-bodied aircraft) have remained state-owned. These are Băneasa (now officially Aurel Vlaicu) and Otopeni (Henri Coandă) in Bucharest along with Constanţa (Mihail Kogălniceanu) and Timişoara (Traian Vuia).

Twelve have been transferred to county [judeţ] administrations that must decide on the future of these facilities and arrange for the sponsorship of any development required. Authority may be transferred to a private company although the state reserves 


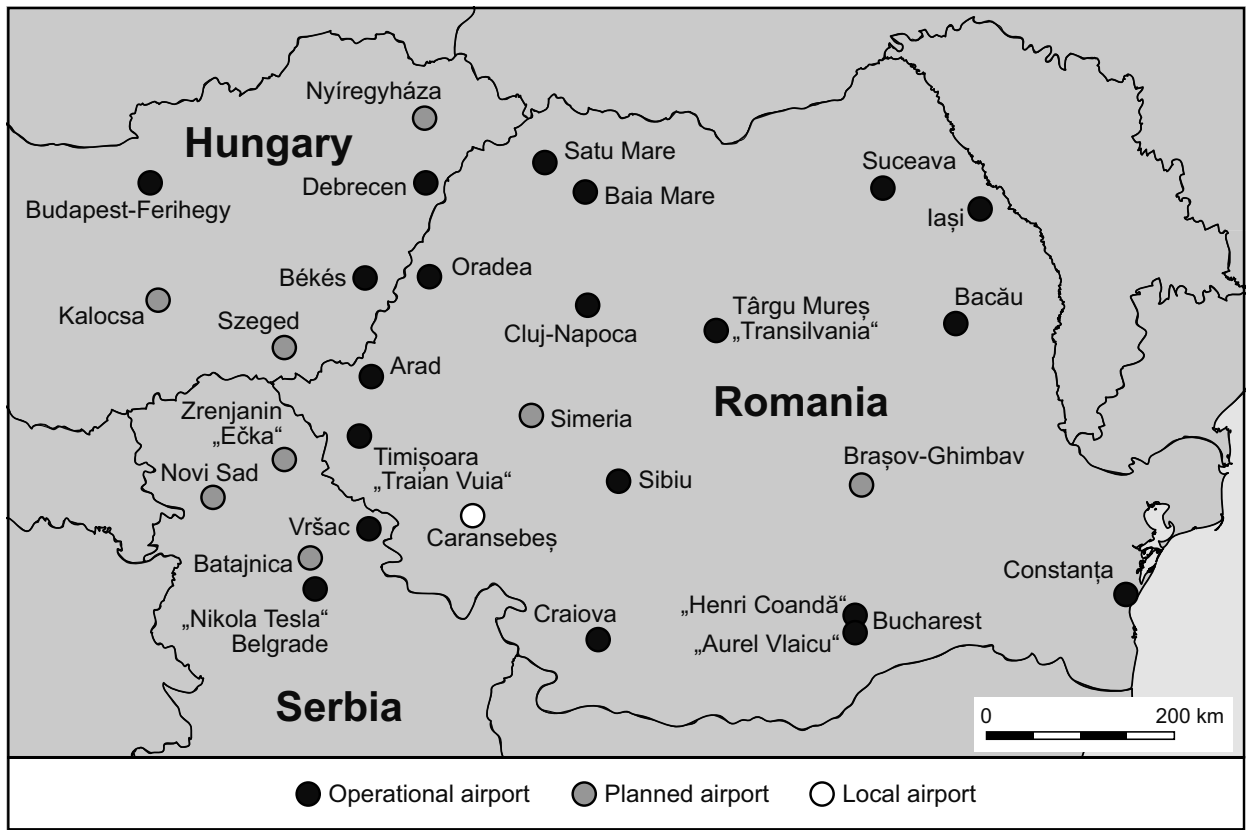

Sources: Ministry of Economy and Transport 2006, Government of Romania 2006, Belgrade City Council 2008, Sosna \& Lucas 2007, Megginson Technologies Ltd.

Fig. 1: Airports in Romania and adjacent areas of Hungary and Serbia

the right to use the facilities for their own purposes in the event of a war or natural disaster (WASsing 2008).

It has emerged that all the county councils are keen to develop their airports as an important means of attracting foreign investment. Indeed, regional airports are particularly attractive in view of the congested roads and limited highway development, when even car travel may be limited to $50 \mathrm{~km} / \mathrm{h}$. Since the state is generally responsible for funding development of road and rail transport (though not national roads in urban areas) airports constitute a unique opportunity for the counties to take initiatives in the transport field; while deregulation has brought changes for airport authorities which are now in competition to attract airlines.

Meanwhile, the airlines are themselves free to behave as footloose companies, with the low-cost airlines especially seeking incentives on the strength of the substantial passenger numbers they attract. Their network structure tends to fluctuate considerably and unpredictably according to economic and political conditions as well as companies' strategic considerations (BuRGHOUwT 2005, pp. 53-57).

Competition can be generated in various ways, e.g. lower airport tax rates - provided governments do not standardise charges and thereby undermine competition (FRANCIS et al. 2003) - and better facilities that will minimise turn-round time. Adequate capacity is obviously a precondition, yet overcapacity - which will inevitably arise (at least in 
the short term) following a major expansion - may be exacerbated if a home-based airline fails or traffic is transferred. But an airport able to offer rush-hour slots may attract an airline away from a competitor that suffers from congestion. And there may also be marketing support for the development of new routes (RPB NETHERLANDS INSTITUTE FOR SPATIAl Research 2005) which may eventually result in additional flights and the use of a particular airport as a base (Graham \& Dennis 2006).

Geographical position is crucial for the success of an airport, with potential typically measured in terms of the population within one hour's travel. So, particularly keen competition may be expected, where passengers have a choice of airports on this basis. Such a situation already arises in Banat due to the proximity of Arad and Timişoara, but there is also scope with regard to three other pairings: Bacău/Iaşi, Baia Mare/Satu Mare and Cluj-Napoca/Târgu Mureş. And competition is likely to increase with further highway construction and the provision of urban bypasses. However, average incomes also have a bearing on numbers, and relatively high per capita purchasing power parity in some cities could boost one airport over another in an airline's calculations.

\subsection{Bucharest: Henri Coandă and Băneasa}

Renamed after Romania's most famous aviator (Henri COAND airport was opened under Communism to restrict the older congested facilities at Băneasa to domestic traffic, while large aircraft were also kept further away from the city centre. Thirty-one foreign airlines (including the low-cost carriers Easy Jet and Clickair) use the airport for scheduled flights, while charters are operated by Romavia, Tarom, Ion Tiriac and Jetran as well as seven foreign companies.

The original terminal building has been upgraded, with $€ 280$ millions invested during 1994-2000 in an expansion programme that included a new departure terminal (1997), an improved arrival area (2000) and a second runway. This is helping to strengthen the role as transit hub for Asia - Europe links with passenger numbers rising from some 2.6 millions in 2005 to 5.01 millions in 2008. There is also some internal traffic due to sound pollution problems at Băneasa in 2000.

And a modern air freight centre has been built by Bucharest International Cargo Centre: a multi-modal cargo platform with an annual capacity of 30,000 t and new road connections in 2001. The MacDonnell Doulas MD11 Combi seems the most likely cargo transport plane for Tarom, but a high level of efficiency will be needed to cope with stiff competition from KLM and Lufthansa, who are also involved in freight operations. A new cargo terminal is due in 2012.

The British Airport Group - representing firms active in airport development - is hoping to share in the work connected with a further $€ 650$ million programme for growth. This will extend to 2020 over 600 ha (requiring the expropriation of some 600 small landowners) to include four new modules/halls (for a total of 80 gates) and a multi-storey car park on three levels. 
For long constrained by the power of the taxi drivers 'cooperative', the airport has now improved its public transport provision with direct access to bus services. Also a Japanese-financed Otopeni-Băneasa roadside monorail (mooted since 2000) has been overtaken by a metro link (initially expected in 2010). And a rail link will be accommodated by a multi-level interchange, replacing the initial rail/bus service that started in 2009.

Local commercial growth includes a four star transit hotel. The fuel situation is being improved by Romanian Fuelling Service - a Romanian-British joint venture involving BP - that will also operate at Băneasa, Constanţa and Timişoara. It involves new equipment by BP to reduce costs and refuelling time. In the process the monopoly of Romarc Fuel will be broken and Tarom's heavy fuel costs (40\% of the company's total expenses) will be reduced by a quarter. Shell have invested in a 14,000 sq.m aviation fuel depot (14,000 sq.m facility), while also funding an upgrade at Petrobrazi refinery.

Băneasa opened in 1920 and its early history has already been noted. With the opening of Otopeni it was able to concentrate on Tarom's domestic flights. However, with the completion of the domestic hall at Otopeni (1997-2000) all Tarom's activities were transferred there after 2000, leaving Băneasa (now known as Aurel Vlaicu) as a facility for business flights. However, it regained an international role in 1998 with passenger and freight facilities as well as daily charter flights to Trieste. After refurbishment it then attracted low-cost flights by Blue Air and Wizz Air experiencing an incredibly rapid rate of growth from 40,000 passengers in 2004 to 0.7 millions in 2006 and 1.8 millions in 2008 .

There was talk of a foreign investor who might finance traffic surface improvements, extend the runway, rehabilitate the beacons and provide new hangars and terminal facilities for passengers and cargo by 2010. But the facilities cannot easily be extended due to the confined site, not to mention the historic status of the terminal building as well as the pollution and safety issues. However, the separation of two Bucharest airports as individual state companies (both with $80 \%$ stakes held by the Ministry of Transport) was overcome in 2007 by proposed amalgamation into a single 'Compania Naţională Aeroporturi București'. This will create a strong company in the European context, although since this unification was not approved until 2009 the continuing competition reduced earnings. Privatisation was contemplated in 2007 and is now envisaged for 2009-10.

With a combined total of 6.8 million passengers in 2008 Bucharest certainly meets EU guidelines of 5-10 millions for a 'national airport'; though not yet the 10 million threshold for a 'large Community airport' (FruhLing 2006, p. 101). But congestion is a major problem and there is a proposal for a new airport for low-cost flights at Alexeni (currently a military helicopter base) in Ialomiţa county near Urziceni which could restrict Băneasa to a luxury role. There is also a proposal for a third Bucharest airport at Adunaţi-Copăceni, near the projected link between the Constanţa and Piteşti highways. This would be particularly appropriate for flights coming in from the south. However, Transport Minister Radu BerceAnu declared in 2009 that this facility will not be needed if there is greater efficiency at Otopeni. 


\subsection{Provincial airports}

By way of a profile, Table 4 lists the airports and supplies details of ownership and as well as ICAO and IATA codes and information on altitude and runway length.

Constanţa and Timişoara are still nationally-owned with relatively high capacity, including the longest runways (some 3,500 m), while Bacău, Craiova and Satu Mare have runways of 2,500 $\mathrm{m}$ at least, compared with 1,800-2,000 $\mathrm{m}$ for the others. Runway length is partly a consequence of military and strategic functions. After many years of heavy use as an important destination for tourist charters, Constanţa was upgraded during 1990-1995 (and subsequently during 2001-2003) as an advanced base for US troops going to Iraq and Afghanistan. The American base remains, although use by the Romanian Air Force (RAF) ceased in 2004. Meanwhile Bacău retains the RAF Base 95 with MiG 21 Lancer fighters, IAR-330L helicopters and training facilities; while the Aerostar aircraft maintenance and manufacturing plant also has an interest. Craiova has links with the Avioane factory (presently under offer for privatisation)

\begin{tabular}{|l|l|l|l|c|c|}
\hline Name & Owner/Operator & ICAO & IATA & $\begin{array}{c}\text { Altitude } \\
\mathbf{m}\end{array}$ & $\begin{array}{c}\text { Runway } \\
\mathbf{m}\end{array}$ \\
\hline Arad* & Arad County Council & LRAR & ARW & 107 & 2,000 \\
\hline Bacău* & Bacău County Council & LRBC & BCM & 185 & 2,500 \\
\hline Baia Mare+ & Maramureş County Council & LRBM & BAY & 184 & 1,800 \\
\hline Caransebeş & Argirom International & LRCS & CSB & 264 & 2,000 \\
\hline Cluj-Napoca*+ & Cluj County Council & LRCL & CLJ & 315 & 2,100 \\
\hline Constanţa*+ & SNAIMKC\# & LRC & CND & 108 & 3,500 \\
\hline Craiova & Dolj County Council & LRCV & CRA & 191 & 2,500 \\
\hline Iaşi* & Iaşi County Council & LRIA & IAS & 121 & 1,780 \\
\hline Oradea* & Bihor County Council & LROD & OMR & 142 & 1,800 \\
\hline Satu Mare & Satu Mare County Council & LRSMN & SUJ & 123 & 2,457 \\
\hline Sibiu* & Sibiu County Council & LRSB & SBZ & 456 & 2,000 \\
\hline Suceava+ & Suceava County Council & LRSV & SCV & 419 & 1,800 \\
\hline Târgu Mureş+ & Mureş County Council & TM & TGM & 294 & 2,000 \\
\hline Timişoara*+ & Romanian Government & LRTR & TSR & 92 & 3,550 \\
\hline Tulcea+ & Tulcea County Council & LRTC & TCE & 85 & 2,000 \\
\hline
\end{tabular}

Legend: * officially an 'international airport'; \# Societatea Naţională Aeroportul Internaţional 'Mihail Kogălniceanu' Constanţa; + most provincial airports use the name of the relevant town, although there is a history of names appropriate top the suburb: Cătaloi at Tulcea, Someşeni at Cluj-Napoca, Tăuţii-Măgherăuş at Baia Mare and Vidrasău at Târgu Mureş. Names: Constanţa has been known as Mihail Kogălniceanu; while Suceava has used the name Ştefan cel Mare.

Table 4: Romania's principal civil airports in the provinces 


\begin{tabular}{|c|c|c|c|}
\hline Airport & Distance+ & Passengers\# & Airlines (charter companies in italics@) \\
\hline Arad & 4 & 130 & Blue Air, Tarom (to 1997) \\
\hline Bacău & 10 & 120 & Austrian Airlines, Tarom \\
\hline Baia Mare & 8 & 22 & Blue Air, Carpatair, Tarom (to 1997) \\
\hline Caransebeş & $43^{*}$ & n.d. & Tarom (to 1994) \\
\hline Cluj-Napoca & 8 & 753 & $\begin{array}{l}\text { Austrian Airlines, Germanwings, Lufthansa, } \\
\text { Tarom, Wizz Air, Air Malta, Blue Air, Karthago } \\
\text { Airlines, Koral Blue Airlines, Nouvelair, Tunisair }\end{array}$ \\
\hline Constanţa & 26 & 80 & $\begin{array}{l}\text { Blue Air, Carpatair, Malév, Ryanair, Tarom, Adria, } \\
\text { Air Berlin, Blue Line, Condor, Germanwings, } \\
\text { Hamburg International, Hapag-Lloyd, Luxair, } \\
\text { SAS, VIM Airlines }\end{array}$ \\
\hline Craiova & 10 & n.d. & Carpatair, Tarom (to 1994) \\
\hline Iaşi & 8 & 146 & $\begin{array}{l}\text { Austrian Airlines, Carpatair, Malév, Tarom, Atlas } \\
\text { Jet, Blue Air }\end{array}$ \\
\hline Oradea & 5 & 31 & Carpatair, Tarom \\
\hline Satu Mare & 14 & 10 & Tarom \\
\hline Sibiu & 5 & 164 & $\begin{array}{l}\text { Austrian Airlines, Blue Air, Carpatair, Lufthansa, } \\
\text { Tarom, Atlas Jet }\end{array}$ \\
\hline Suceava & 11 & 14 & Carpatair, Tarom \\
\hline Târgu Mureş & 12 & 47 & $\begin{array}{l}\text { Cimber, Malév, Tarom, Wizz Air, Aegean Air- } \\
\text { lines, Blue Air }\end{array}$ \\
\hline Timişoara & 12 & 957 & $\begin{array}{l}\text { Austrian Arlines, Carpatair, Lufthansa, Malév, } \\
\text { Moldavian Airlines, Wizz Air, Aegean Airlines, } \\
\text { Air Malta, Atlas Jet, Blue Air, Jetran Air, Nouve- } \\
\text { lair, Romavia }\end{array}$ \\
\hline Tulcea & 3 & n.d. & Tarom (to 1996) \\
\hline
\end{tabular}

Legend: + Distance in relation to the town centre; * Distance to the county town of Reşiţa; \# Passenger numbers in thousands for 2008; @ Of the charter operators listed the following also fly into Bucharest Otopeni: Air Malta, Atlas Jet, Jet Tran Air (also Băneasa), Karthago Airlines, Koral Blue Airlines, Nouvelair (also Băneasa) and Romavia. There are also a number of charter companies which use Otopeni, but no provincial airports: Air Cairo, Air Europe, Eurojet Romania (Băneasa only) and Ion Tiriac.

Table 5: Romania’s provincial airports: airlines and passenger numbers

associated with the construction of IAR-93 and IAR-99 aircraft. And military use also arises at Timişoara because - although the RAF base was disbanded in 2004 and some planes transferred to Câmpia Turzii - over 30 MiGs remain in store; while a helicopter transport base continues to operate. Meanwhile Satu Mare's relatively good facilities arise from its former value to the Warsaw Pact already noted. 
Table 5 deals with passenger numbers (in 2008) and the airlines which use each facility; also the distance from the relevant town or city: generally no more than $14 \mathrm{kms}$ but $26 \mathrm{kms}$ for Constanţa (to reach Mihail Kogălniceanu), while the town of Reşiţa is $43 \mathrm{kms}$ from Caransebeş (although scheduled flights are discontinued).

Clearly there are vast differences in passenger numbers with Cluj-Napoca and Timişora at one extreme (0.75-1.00 millions) while four fall into a group of 10-31,000: Baia Mare, Oradea, Satu Mare and Suceava.

This is confirmed by the number of airlines operating into each airport: Caransebes and Tulcea have no scheduled services, while Arad, Craiova and Satu Mare have only one scheduled passenger operator and Bacău, Baia Mare and Suceava have two. At the other extreme Cluj-Napoca has 11, Timişoara 13 and Constanţa 15 (though the rankings are rather different for scheduled flights with five each for Cluj-Napoca and Constanţa and six for Timişoara).

When destinations are considered (see Table 6) there is a grand total of 125: 92 foreign and 33 domestic. Timişoara is clearly in the lead with 27 foreign desinations and eight domestic, followed by Cluj-Napoca (22 foreign and two domestic) and Constanţa ( 19 foreign and four domestic): a total of 82 which is two-thirds of the grand total.

Sibiu is a long way behind (five foreign and four domestic); also Bacău and Iaşi with a total of seven each. However, when charter flights are taken out of the picture (15 routes at Constanţa, seven at Cluj-Napoca, three at Iaşi and one each at Oradea and Suceava), then Timişoara with 35 destinations in all and Cluj-Napoca with 17 dominate the picture: 52 destintions out of $96(54 \%)$, since no other airport reaches double figures.

It is interesting to see how the foreign services are dominated by flights to just five countries (Austria, France, Germany, Italy and Spain): 48 out of a total of 62 for scheduled flights, but only six out of 29 for charter flights which are geared overwhelmingly to holiday destinations.

Another interesting analysis considers recent trends in passenger numbers (see Table 7). Provincial airports have generally experienced growth in recent years, but this does not apply universally, because Constanţa which registered 779,000 passengers in its record year of 1979 had only 80,000 in 2008 .

As already noted, two regional airports are in a class of their own: Timişoara with 957.0 thousand passengers in 2008, and Cluj-Napoca with 753.0. But the increase since 2005 has been 'only' 56\% at Timişoara compared with an almost four-fold growth at Cluj-Napoca. Indeed the progress of Cluj-Napoca has been quite outstanding with just 59.4 thousand passengers in 1999 rising to 75.7 in 2000, 105.1 in 2002 and 162.7 in 2004.

The two leaders are followed by a group of five in the bracket 120-164,000 comprising Sibiu (with the highest figure) along with Târgu Mureş, Iaşi, Arad and Bacău (the lowest); while the remaining six are all well below 100,000, and in one case (Tulcea) there are no longer any scheduled passenger flights at all.

However, with EU guidelines quoting 1-5 millions as the standard for a 'large regional airport', all Romania's installations will remain 'small', at least for the time being (FRUHLING 2006, p. 101). 


\begin{tabular}{|c|c|}
\hline Airport & Destinations \\
\hline Arad & *Bucharest-Băneasa, Reus, Valencia, Verona, Venice-Treviso \\
\hline Bacău & $\begin{array}{l}\text { Bologna, Bucharest-Otopeni, Milan-Orio al Serio, Rome-Fiumicino, } \\
\text { Suceava, *Timişoara, Torino-Cuneo }\end{array}$ \\
\hline Baia Mare & *Bucharest-Otopeni, Vienna \\
\hline Cluj-Napoca & $\begin{array}{l}\text { Antalya, Barcelona, Bologna, *Bucharest-Otopeni, Barcelona, Budapest, } \\
\text { *Constanţa, Corfu, Dortmund, Frankfurt, Heraklion, London-Luton, Madrid, } \\
\text { Malta, Milan-Bergamo, Monastir, Munich, Paris-Beauvais, Rhodos, Rome- } \\
\text { Fiumicino, Sharm El Sheikh, *Timişoara, Treviso, Valencia, Vienna }\end{array}$ \\
\hline Constanţa & $\begin{array}{l}\text { Athens, Bologna, *Bucharest-Băneasa, Brussels, Budapest, *Cluj-Napoca, } \\
* \text { Craiova, Düsseldorf, Hamburg, Harstad, Istanbul, Kristiansand, Ljubljana, } \\
\text { Luxembourg, Milan, Moscow, Munich, Oslo, Paris-Charles de Gaulle; Pisa, } \\
\text { Strasbourg, Stavanger, *Timişoara }\end{array}$ \\
\hline Iaşi & Antalya, Bodrum, *Bucharest-Otopeni, Budapest, Salonica, *Timişoara, Vienna \\
\hline Oradea & Antalya, *Baia Mare, *Bucharest-Otopeni, *Satu Mare, *Timişoara \\
\hline Satu Mare & *Bucharest-Otopeni, *Oradea \\
\hline Sibiu & $\begin{array}{l}\text { *Bucharest-Băneasa, *Bucharest-Otopeni, Köln/Bonn, Madrid, Munich, } \\
\text { Stuttgart, *Târgu Mureş, *Timişoara, Vienna }\end{array}$ \\
\hline Suceava & Antalya \\
\hline Târgu Mureş & Antalya, *Bucharest-Otopeni, Budapest, Heraklion, *Sibiu \\
\hline Timişoara & $\begin{array}{l}\text { Ancona, Athens, Barcelona, Bari, Bologna, *Bucharest-Otopeni, Budapest, } \\
\text { Chisinău, *Cluj-Napoca, *Constanţa, *Craiova, Dortmund, Düsseldorf, Florence, } \\
\text { Forli, Frankfurt, *Iaşi, Kiev-Zhuliany, London-Luton, L'vìv, Milan-Bergamo, } \\
\text { Munich, *Oradea, Paris-Beauville, Rome-Fiumicino, }{ }^{* S \text { Sibiu, Stuttgart, *Suceava, }} \text {, } \\
\text { Salonica, Torino, Valencia, Venice-Treviso, Verona, Udine, Vienna }\end{array}$ \\
\hline Tulcea & no information \\
\hline
\end{tabular}

Source: Airline and airport websites

Table 6: Romania's regional airports: flight destinations. Destinations asterisked are Romanian; those underlined are reached by two different carriers (three Karthago Airlines, Nouvelair and Tunisair - in the case of charter flights from Cluj-Napoca to Monastir)

Analysis of passenger numbers for 2005-2008 - a period of unprecedented growth - shows that numbers increased in Bucharest (both airports) from 2.80 to 6.83 millions $(144 \%)$, while the ten leading provincial airports increased at a rather slower rate of $107 \%$ from 1.22 to 2.44 millions declining from $30.3 \%$ of the grand total of 4.02 millions in 2005 to $26.3 \%$ of 9.27 millions in 2008 (see Table 7).

However, the performance of the provincial airports (see Fig. 1) has been very variable. Several have exceeded Bucharest's growth rate: Cluj-Napoca (271\%), Iaşi (248\%), Sibiu (169\%), Arad (155\%) and Constanţa (151\%). But the others have grown much more slowly: Suceava (80\%), Timişoara (69\%), Oradea (12\%) and Bacău (9\%). And Târgu Mureş suffered a substantial decline (-35\%) with the transfer of Wizz Air 


\begin{tabular}{|l|r|r|r|r|r|r|r|}
\hline \multirow{2}{*}{ Airport } & \multirow{2}{*}{$\mathbf{2 0 0 5}$} & \multirow{2}{*}{$\mathbf{2 0 0 8}$} & \multirow{2}{*}{$\begin{array}{l}\text { Percent } \\
\text { Growth }\end{array}$} & \multicolumn{2}{|c|}{ Shares (All) } & \multicolumn{2}{c|}{ Ditto(Provincial) } \\
\cline { 5 - 9 } & & & $\mathbf{2 0 0 5}$ & $\mathbf{2 0 0 8}$ & $\mathbf{2 0 0 5}$ & $\mathbf{2 0 0 8}$ \\
\hline Bucharest Total & $2,570.0$ & $6,832.2$ & 165.8 & 67.9 & 73.7 & & \\
\hline Bucharest Băneasa & 385.0 & $1,768.0$ & 359.2 & 10.2 & 19.1 & & \\
\hline Bucharest Otopeni & $2,185.0$ & $5,064.2$ & 131.8 & 57.7 & 54.6 & & \\
\hline Provincial Total & $1,217.9$ & $2,442.3$ & 100.5 & 32.1 & 26.3 & 100.0 & 100.0 \\
\hline Arad & 51.3 & 130.0 & 153.4 & 1.4 & 1.4 & 4.2 & 5.3 \\
\hline Bacău & 110.0 & 120.0 & 9.1 & 2.9 & 1.3 & 9.0 & 4.9 \\
\hline Cluj-Napoca & 202.6 & 753.0 & 271.7 & 5.3 & 8.1 & 16.7 & 30.8 \\
\hline Constanţa & 32.0 & 80.2 & 150.6 & 0.8 & 0.9 & 2.6 & 3.3 \\
\hline Iaşi & 42.0 & 146.0 & 247.6 & 1.1 & 1.6 & 3.5 & 6.0 \\
\hline Oradea & 27.8 & 31.2 & 12.2 & 0.7 & 0.3 & 2.3 & 1.3 \\
\hline Sibiu & 60.7 & 164.0 & 170.2 & 1.6 & 1.8 & 5.0 & 6.7 \\
\hline Suceava & 7.7 & 13.9 & 84.0 & 0.2 & 0.1 & 0.6 & 0.6 \\
\hline Târgu Mureş & 72.1 & 47.0 & -34.8 & 1.9 & 0.5 & 5.9 & 1.9 \\
\hline Timişoara & 611.7 & 957.0 & 56.4 & 16.2 & 10.3 & 59.2 & 39.2 \\
\hline Grand Total & $\mathbf{3 , 7 8 7 . 9}$ & $\mathbf{9 , 2 7 4 . 5}$ & $\mathbf{1 4 4 . 8}$ & $\mathbf{1 0 0 . 0}$ & $\mathbf{1 0 0 . 0}$ & & \\
\hline
\end{tabular}

Source: Airport websites

Table 7: Romania: airport passengers (in thousands) 2005-2008. No comparable data for Baia Mare, Caransebeş, Craiova and Satu Mare: hence the grand totals are smaller than the national totals

flights to Cluj-Napoca. However, Timişoara retains its top position and Cluj-Napoca has consolidated its second place, while Sibiu has moved into third place, overtaking Bacău and Târgu Mureş (slipping to sixth and eighth respectively), and Iaşi jumps from seventh to fourth place (at the expense of Arad as well as Bacău and Târgu Mureş). Constanţa also overtakes Târgu Mureş to claim seventh place while Oradea and Suceava remain in ninth and tenth place, respectively.

Of the airports covered in Table 6, Timişoara's share of the provincial total has fallen from 50.2 to $39.2 \%$ - also Bacău (9.0 to 4.9\%), Târgu Mureş (5.9 to $1.9 \%$ ), Oradea (2.3 to $1.3 \%)$; while all the others have increased - Cluj-Napoca from 16.6 to $30.8 \%$, Sibiu from 5.0 to $6.7 \%$, Iaşi from 3.5 to $6.0 \%$, Arad from 4.2 to $5.3 \%$ and Constanţa from 2.6 to $3.3 \%$ - apart from Suceava which is stable at $0.6 \%$.

For aircraft movements the provincials combined (leaving aside Constanţa, Oradea and Suceava) have 75,955 which is $43.3 \%$ of Bucharest's figure of 115,464 in 2008 . However, among the provincials, high shares of $49.5 \%$ for Timişoara and $39.6 \%$ for Cluj-Napoca (both well above their passenger shares) reflect the importance of freight and light aircraft.

There are of course different criteria for success. Craiova has done well recently - mainly through charter business until 2007, when regular services started to Milan 
via Timişoara. Now two cargo companies are interested: Jet Technics and Air Jet. And there is also a possible Blue Air Bucharest - Barcelona stop-off as well as Air One Italia direct flights to Milan; while talks have been held with Ryanair. There has also been a boost from the Pirelli and Ford industrial interests (Pirelli being especially significant for links with Milan). However, facilities will have to improve, because one runway is insufficient; yet there are difficulties over acquiring adjacent land from the Ministry of Defence.

\subsection{Regional studies: Transylvania [Ardeal] and Marmarosh [Maramureş]}

There is certainly much development activity in hand, with Transylvania perhaps the most outstanding region.

Cluj-Napoca is implementing a $€ 100$ million development plan including runway reconstruction and a cargo terminal with money from the County Council and the EU. A new terminal was provided during 1996-2001; followed by a runway extension from 1,850 to $2,100 \mathrm{~m}$ in 2006 (3,500 $\mathrm{m}$ is planned) requiring deviation of the Someș River in 2001. A new terminal - known as the 'Schengen Complex' - was under construction during 2007-2009.

The city now has a wide range of international connections and further interest is being shown by Air France and British Airways. However, further airport development is threatened by 'Turnurile lui Paszkany', the two skyscrapers ('zgârie nori') being built in connection with Arpad PaszKany's 'Sigma Development Center'.

Cargo is a significant business - rising from $73.1 \mathrm{t}$ in 2002 to $313.0 \mathrm{t}$ in 2005. Indeed, a new cargo terminal is planned to meet the needs of Nokia, who intend to bring in two cargo flights daily to support their manufacturing facility on the nearby Tetrarom estate at Jucu.

In 2007, Vienna International Airport expressed interest in a possible privatisation - anticipated in 2009.

At Sibiu, German investors (including companies administering Frankfurt, Munich and Stuttgart airports) are getting involved; along with members of the business club Ost-West Wirtschaftsclub Bayern interested in airport administration. $€ 50$ millions is now being spent on modernisation ( $€ 22$ millions from the government, and the rest from the city and county using their own funds and an EIB loan). The work is being done by the German Lindner company as well as a local company (Con-A) and Dafora from Mediaş. In 2008, the runway will accommodate the Airbus 380 and there are now enough Austrians based in the city to justify weekend flights to Vienna.

Târgu Mureş has been upgrading through a $€ 60$ million investment including a new terminal and landing system in 2005 . And there has also been progress since 1994 to realise the concept of an adjacent 'Free Economic Zone'. This involves an industrial park project started in 2004 with the help of the Geiger Group (Germany) and the initial area of 20 ha has now been doubled. There is also a $€ 12$ million cargo zone project, and weekly Cimber Air flights started operating to Copenhagen 2009. 
At Baia Mare international flights started in 2008, with Austrian Airlines flying three days/week to Vienna. This was a big improvement, because previously it was necessary to travel to Budapest or Cluj-Napoca for international flights.

Upgrades are also reported at Oradea and Satu Mare including runway extensions to attract international links, while the latter stands to benefit from a large industrial park project linked with air transport.

Reference should also be made to completely new airport projects.

At Braşov the County Council (BCC) have concluded a protocol with Gunay (Turkey) for an international airport (at Ghimbav on the northern side of the city) to be included in the ring road programme. Gunay will finance the building and operate the airport for a period before it becomes the council's property. Another news item refers to development at Ghimbav during 2006-2010 involving a $€ 100$ million contract between $\mathrm{BCC}$ and Itelcan. However, BCC are still looking for finance from European banks.

A new airport at Alba Iulia could emerge through enlargement of the present aerodrome at Vinţul de Jos (currently available for aircraft with fewer than 30 passengers). Although extra land will have to be obtained by expropriation, this is a cheaper option than an entirely new facility nearer to Alba Iulia.

Finally, at Bistriţa, the local authority wants a new airport and a motorway link (with Cluj-Napoca) while developments are mooted at Deva-Hunedoara as explained below.

\subsection{Regional Studies: Moldavia [Moldova]}

There is also activity in Moldavia, where the Transport Minister suggested in 2000 that Bacău, Iaşi and Suceava should aspire to international airport status. Both Bacău and Iaşi are generating substantial passenger numbers.

Bacău has completed an upgrade including a 2,500 m runway and has secured flights to Bologna, Rome, Trieste and Verona by Carpatair from 2002. Bacău also secured a back-up function for Chişinău in Moldova (since both Iaşi and Suceava had shorter runways at the time, i.e. 1,800 m). Italian businessmen are involved in environmental protection, and town planning has secured a helicopter for emergency medical cases; while a public-private partnership has been announced which will secure an investment of $€ 45$ millions by Blue Air during a 35 year concession.

At Iaşi the County Council started investing on the strength of an agreement with Angel Airlines over Bucharest flights. But international flights to Germany, Greece, Italy and Turkey were also priorities, as well as connections through Budapest. Iaşi has now secured a Vienna service run by Austrian Airlines four times weekly, and in fact Vienna airport is interested in assisting further modernisation at Iaşi.

Meanwhile Suceava, which already receives calls by Bucharest - Černìvci flights, hopes to start on a runway extension (to 3,400 m) during 2008-2009. Both the General Consulting Company (representing an international operator) and Carpatair are interested in leasing the airport with a view to enlargement and upgrading to international standards. 
Finally in the south, Galaţi and Brăila together have negotiated with the Italian company Imprenditoriale Sincogero s.p.a. over a new airport between the two cities. This will be part of an ambitious project to integrate the two cities with new housing and road developments.

Clearly, if all these plans come to fruition, Romania will have a very good regional coverage. But there will also be great scope for competition (perhaps too much!), e.g. with Galaţi challenging Constanţa which is already handicapped by a lengthy journey from the city which increases the scope for express railway services.

But Alba Iulia and Bistriţa have ambitions in Transylvania, where the impressive progress of Cluj-Napoca has to be considered in an area where Baia Mare and Satu Mare are also seeking to increase their business.

Thus, Romania is in the process of developing a number of provincial 'multiairport regions' (MARs). At this point the study focuses on the West Region, where local competition is intensified by the cross-border dimension.

\section{The case of the West Region and its cross-border relations}

In this section we make a more detailed analysis of the situation in what is often portrayed as Romania's most dynamic region (www.adr5vest.ro/news; www.inforegio.ro).

The region is well served by airports at Arad and Timişoara (Traian Vuia) (see Fig. 1). Both wish to expand and yet, lying only $54 \mathrm{kms}$ apart, their hinterlands overlap quite massively, if the one-hour rule is applied. This provides Romania's best example so far of a MAR, where competition will reflect both level-of-service attributes as well as airport facilities (Loo 2008, p. 117).

Moreover, it cannot be assumed that there will be no further competition from within the region, since they are both situated at the western edge a long way from such population centres as Deva/Hunedoara and Petroşani. There is already a third airport at Caransebeş: used in the later Communist period for flights to serve the Caraş-Severin county town of Reşiţa and, so far, the only private airport in the country. It is owned by Argirom International which is a trade and tourism firm with a major interest in the spa resort of Băile Herculane in 2001. The airport is seen as important for charter flights and $€ 2.0$ millions have already been invested at Caransebes (to 2007) to extend the runway for larger (charter) aircraft with funding from Argirom and an Israeli partner Avivim. This airport could widen its activities further, while the projected amalgamation of the three towns of Deva, Hunedoara and Simeria, to create the basis of a new regional centre with scope for a $€ 40$ millions airport project at Simeria. This project has reached the stage of a feasibility study by an Italian company.

However, additional interest in this region arises from the cross-border dimension, because the region's leading airports will have to cope with the growth of facilities in adjacent areas of Hungary and Serbia which are already extending the influence of their respective capital cities: Budapest and Belgrade. 


\subsection{Timişoara}

This city is the leading centre of the region at the heart of its dynamic economic core (www.cjtimis.ro; www.primariatimisoara.ro; www.adetim.ro; www.timis.insse. ro). It's highly successful airport is owned by the state $(80 \%$ by the Ministry of Transport, Construction and Tourism and $20 \%$ by Fondul Proprietatea) and enjoys financial autonomy. It was opened in 1935 close to Moşniţa Veche village and it has a history of military use. But the present facilities date to the 1960s with subsequent developments. The terminal building of 1964 has been enlarged (since 2003), while the runway was extended from 2,500 to 3,500 $\mathrm{m}$ in 1980 .

The airport has grown very rapidly since 1989 in sympathy with the city's economic fortunes, and various recent improvements have been made to attract more traffic with government support. 40-50 flights are handled during an average day including 20-25 (350 passengers) during the peak (ADETIM 2006). Growth has been very rapid with passenger numbers increasing more than four times from 223.1 thousands in 2000 to 403.1 in 2004 and 957.0 in 2008. Indeed, the airport took fifth place in Europe for growth exceeding 50\% over the two years 2005/06 (European Communities 2007).

There is, however, a dispute over the issue of greater local control, because while Timiş County Council (TCC) would like to take over, the Ministry has to consider the airport's national role - as a reserve airport for Bucharest, Budapest and Belgrade - and is not convinced that there is adequate financial support. Hence, the plan to transfer authority in 2009 has been delayed (WASsING 2008).

Fortunately there is no dispute within the local area, since the airport is greatly valued by both TCC and Timişoara Council, while political parties are supportive given the commercial opportunities and the low-cost flights on offer. According to operational director Marian CHIvU, the present board seeks ongoing route development (both within and beyond the limits of the EU).

Indeed, a $€ 385$ million modernisation and development plan (financed from public and private sources) was launched in 2005 . This will raise capacity to 2.7 million passengers during 2006-2015 and also create a business and logistics park over 50-60 ha nearby. This plan has financial support from both TCC and the Italian company Sane: the latter's $60 \%$ contribution will include the aircraft maintenance facility, a business terminal, a commercial centre, a modern car park and access roads. Capacity will double from three to six flights per hour, when the new terminal is finished and this will allow separate handling of passengers from outside the Schengen zone to minimise the risk of illegal entry to the EU and control drug smuggling.

Hotels are expanding in the vicinity of the airport, and politicians from the National Liberal Party have already encouraged the opening of an airport business lounge much appreciated for conferences and meetings. Access will improve with the completion of the highway link between Budapest and Bucharest which is due to connect with the airport pass close to the airport in 2013.

Aircraft movements have increased massively from 7.4 thousand in 2000 to 22.7 in 2005 and 49.5 in 2008. Six airlines are operating out of the airport: Austrian Airlines, Carpatair, Lufthansa, Malév, Tarom and Wizz Air, with the majority of flights made 
by Carpatair and Tarom. There is a strong emphasis on flights to Western Europe: ten destinations in Italy, five in Germany and one each in Austria and the United Kingdom. This reflects the high level of German and Italian investment in the area, although many Romanians work in Italy and travel home for holidays.

Carpatair is particularly interesting, because it uses Timişoara as its hub to serve the business community. As already mentioned, passengers are flown in from the east in the early morning for onward journeys to the west. These are mainly in Italy (Ancona, Bari, Bergamo, Bologna, Florence, Rome, Torino, Venice and Verona) but also Germany (Düsseldorf, Frankfurt, Munich and Stuttgart) as well as Austria (Vienna) and Greece (Athens and Salonica). With the process reversed later in the day (albeit with short turn-round times) there are many options for day-return trips to Western Europe.

However, there is also heavy demand for air flights to Bucharest to visit government offices and company headquarters. Meanwhile, Wizz Air, which initially offered flights from Cluj-Napoca to Germany and Italy, has been competing at Timişoara since December 2008. It operates thrice-weekly flights (increased to four from March 2009) to London, Dortmund and Rome, alongside other routes to Barcelona, Milan, Paris, Valencia and Venice. A tourist helicopter link with Băile Herculane started in 2001 and still operates. Some Tarom international flights call at Timişoara, e.g. the Florence service with connections from Satu Mare.

Since resuming its flights to Romania in 1994, British Airways have been considering passenger, cargo and mail services to Timişoara. And expansion now necessitates a separate terminal for 'low-cost' flights to support further growth arising from the Wizz Air base being established in 2009. This is linked with services to Barcelona, London, Milan-Bergamo, Paris-Beauvais, Rome, Valencia and Venice-Treviso.

Of course there have also been set-backs and over the 2004-2007 period a number of initiatives have failed including Tarom's links with Constanţa and Frankfurt as well as the long-haul destinations of Chicago and New York; also Alitalia flights to Milan-Malpesa. Other withdrawals include Alpi Eagles (Venice); Blue Air (Munich and Stuttgart); Carpatair (Paris, Venice-Treviso); Club Air (Bari, Verona and Pescara); JAT Airways (Belgrade); and Sky Europe (Vienna). However, some of these decisions arose through competition by other airlines, while others (like Tarom's long-haul flights) arose out of company decisions unconnected with the local situation.

Meanwhile, cargo traffic is increasing slowly from $637 \mathrm{t}$ in 2000 to $1,166 \mathrm{t}$ in 2007 as the city has become attractive for German and Italian investors in clothing and footwear, food processing and car components. Some factories are emerging close to the airport for convenience with regard to air cargo: particularly appropriate for perishable goods and others requiring quick delivery (although road transport also retains an important role). Indeed, a new cargo centre is planned to cope with additional traffic and there are proposals for a road-rail-air intermodal transport facility nearby at Giarmata.

Cargo flights are operated by ABC Air Hungary, Farnair Hungary, FedEx Express, Kuehne-Nagel, Sabiko International Air Cargo, Tarom Cargo, TNT Airways, Tristar and UPS World Media Trans. 
Finally, charter services are operated by Air Malta (Malta), Aegean Airlines (Corfu [Kérkyra]), Atlas Jet (Antalya), Blue Air (Antalya, Bodrum, Heraklion [Erákleion]), Carpatair (Corfu, Salonica, Rhodos [Ródos]), Jetran Air (Antalya, Heraklion, Palma de Mallorca), Karthago Airways (Monastir), Nouvelair (Monastir), Romavia (Zakynthos [Zákunthos]).

\subsection{Arad}

Arad International Airport dates back to 1917 as a military facility with a hangar, terminal and a grass runway. The present terminal was built in 1936, when passenger flights were operating and the airport was refurbished with a 2,000 m concrete runway in 1953. It is now purely a civil airport handling domestic and international flights.

Unlike Timişoara it is now managed by a county-owned company which is keen to develop the airport as catalyst for the further expansion of the regional economy. But the county's financial position is relatively weak compared with national government. Privatisation was anticipated in 2007/08 with investment to follow by way of a terminal extension, but this is all now scheduled for 2010 .

In 1998, there were Tarom flights to Bucharest, while the Italian company Alpi Eagles flew to Verona and Rome thrice weekly. But Tarom cancelled its Bucharest flights in 2005 (rendered unprofitable due to competition), while Alpi Eagles has suspended all its flights at the beginning of 2008 in the face of acute staffing problems. However, Tarom intend to resume a thrice-weekly service from Bucharest and Arad to Venice/Treviso, while an Arad - Stuttgart service is also anticipated. Moreover, a cargo terminal was approved in 1998 in the context of Phare CBC (Agenţille DE Dezvoltare ECONOMico-Socială 1998).

At present, Blue Air operates a daily flight to Bucharest; also to Italy (Venice and Verona) twice weekly and to Spain (Valencia) once. Early in 2008, Ryanair started flights to Milan (attracting 4,000 passengers each month), but the service was withdrawn after only four months amidst mutual recriminations over failure to honour agreements.

Arad has a cargo terminal situated near the town's free zone established in 1999. It can handle perishable goods and is well-situated for interchange with road and rail services. There is also progress relating to a 120 ha commercial area as part of the Arad-Curtici free zone with a cargo terminal (including storage and distribution). This is backed by $€ 2.0$ millions of Phare assistance in the context of cross-border cooperation and the Danube-Criş-Mureş-Tisa Euroregion in particular.

Arad also has combined transport facilities, including a container warehouse and rail access, while further assistance was expected in 2002 from investors from companies (based in Hong Kong, Malaysia, Germany and USA) interested in the development of European Corridor Four. 


\subsection{Cross-border perspectives: Hungary}

There is an important wider issue of competition involving Hungarian and Serbian airports. In the case of Hungary, the nearest facilities are at Békéscsaba, Debrecen and Szeged - while the local authority at Kalocsa has expressed a desire (in 2006) to take over an old military airfield. There is plenty of scope for local initiative since the Hungarian government decentralised control of regional airports in 2001. This was in response to the lack of central funding for developing as well as pressure from county [megye] councils and municipalities (since the mid-1990s) to take over installations important for regional development.

Thus there is now very strong support for the development of an airport at Szeged to stimulate regional development (especially foreign investment including tourist projects). And given the proximity of the Corridor Four highway system (crossing the frontier at Nădlac), this has the potential to attract more traffic from Romania in future under the one hour rule (KISs 2007). A landing strip of 1,185 m was completed at Szeged in 2006 (though it must be extended to 2,500 m), while a terminal building is also needed.

There is also a facility at Békéscsaba with good safety/security arrangements. But it will not offer serious competition as long as the landing strip (1,300 m) limits use to $15 \mathrm{t}$ planes (20-25 persons) and there is no highway access. Indeed, only 200 flights were recorded in 2007: mainly private jets, some of which were stopping only for fuel or emergencies (W ASSING 2008).

Debrecen also enters the picture as a regional airport with a mail service in 1930 and subsequent military and sporting functions (including use as a bomber base during the Second World War). After use by the Soviets during the Communist period the local authority took control in 1994. A comprehensive development plan was launched in 2001 and investment continues to serve flights that go mainly to Germany (Dresden, Hamburg and Leipzig/Halle), but also Bulgaria, the Czech Republic and Tunisia. A runway extension and a cargo base are scheduled for 2007-2012.

But Budapest (Ferihégy) also enters the picture in view of its extensive programme of flights (as one of the largest airports in East Central Europe: eight million passengers in 2005). It lies $220 \mathrm{kms}$ from Oradea and $260 \mathrm{kms}$ from Timişoara very conveniently on the eastern side of Budapest with access via the orbital highway. It also offers a newly-opened terminal for low-cost airlines. Ferihégy has been run as a public private partnership (PPP) since 2005: $25 \%$ owned by the state and $75 \%$ by BAA, who subsequently sold out to Hochtief Airport Consortium, who are now proceeding with a five-year/€ 260 million investment programme.

\subsection{Cross-border perspectives: Serbia}

Serbia also offers competition. Starting as the home of the 'Naša Krila' (Our Wings) aeronautical club in 1925, Vršac became one of Serbia's international airports in 2006. Although it is mainly used for air-taxi and agricultural purposes as well as aircraft maintenance and pilot training (accommodated in five hangars), this role has drawn 
an international reputation dating back to the training of glider pilots (from 1954) and involvement in recreational aeronautics. It now offers a 1,200 m runway which is to be extended to $1,800 \mathrm{~m}$.

The Novi Sad airport at Čenek (16 kms north of the city) is a new facility dating to 1994 and it is still incomplete, although a 2,500 m runway (for 70-80 seater aircraft) is intended. At present, there is a grass runway of some $1430 \mathrm{~m}$ handling small business flights in addition to sporting and agricultural functions, though it is not available in all weathers. There are no scheduled flights, although a Montenegrin airline operated a promotional flight in 2004 using a Turbolet aircraft to highlight further potential.

An airport was also built in Zrenjanin (Bagljaš) in 1929 and became very important for the German Luftwaffe during the Second World War for operations against the Yugoslav resistance. It was subsequently destroyed as a precautionary measure, when Tito's dispute with Stalin and the Cominform assumed major political proportions. But a new airport has now been opened by the municipality [opština] (in 1977) at Ečka, lying seven kilometers southeast of the town. And although this is registered as a sport and trade airport - also used for pilot training - it is destined to become an international airport in the future. $A € 3.0$ million reconstruction of the old German concrete runway is envisaged to handle passenger and cargo flights. Vizium Air of Austria (linked with Diamond Aircraft, Europe's largest producer of sports aircraft) have announced $\mathrm{a} € 30$ million investment to produce sport aircraft at Zrenjanin which (along with a service centre and flying school) will provide 400 jobs.

Meanwhile the capital city of Belgrade is close enough $(211 \mathrm{kms}$ from Arad and 159 from Timişoara) to require consideration. The old airport at Pančevo (operating from 1923) has a 1,000 m runway used largely for recreational functions; while Dojno Polje (opened in 1927 and rebuilt after war damage in 1944) was closed in 1964 to make way for the development of the Novi Beograd suburb. All traffic was then transferred to Surčin, $12 \mathrm{kms}$ west of the city centre. It was built from scratch during 1958-1962 in conformity with the city's growth plan drawn up in 1950. With a 3,000 m runway, this airport has gained the highest international classification, with much attention to safety/security as well as catering and shopping. It is now the hub for JAT Airways, and its freight capacity has doubled from 35,000 to 70,000 t/year.

Nearby is the Batajnica military airport built to help defend the city during 1947 1951 as the Cominform crisis developed. It is now a major Serbian Air Force base and was bombed during the NATO intervention in Kosovo in 1999, although a visit by US jets in 2006 signalled the resumption of military cooperation. It is proposed that this installation should be developed for cargo traffic and low-cost passenger flights with funding from central government or private sources (http://www.beograd.rs/ download.php/documents).

\subsection{Discussion}

The West Region is clearly in a good situation regarding its airports although the present economic slow-down may call for some short-term adjustments in terms of employment and flight costs. But over the longer term air traffic seems set to expand 
rapidly with airport capacity keeping pace with passenger demand (ALEXA 2001, pp. 35-36).

But expansion will inevitably be accompanied by growing competition (DUMITRESCU \& BAL 2002, p. 39). This provides a challenge for the airports to match capacity with demand, while remaining competitive and avoiding a decrease in passenger numbers (Madas \& Zografos 2008, pp. 223-224).

Arad and Timişoara are clearly in competition, falling as they do within the economic core of the West Region. While Arad has supported Timişoara as the key international airport for a trans-frontier region, it will naturally want to see a clear role emerging for its own local airport, although it is at a clear disadvantage over finance (ADETIM 2006, PAVEL 2004). Ryanair favoured Arad, because the required timeslots were not available at Timişoara, but unfortunately the arrangement still broke down due to taxation.

Further afield, Oradea has the ambition to attract international flights, although it currently offers only a Tarom flight to Bucharest apart from the Carpatair feeder already noted. Oradea's passenger numbers actually fell from 41.9 thousand in 2004 to 36.0 in 2005 and remained at this level in 2008. The wooing of Ryanair and Wizz Air in 2006 did not bear fruit, although there is a possibility that EuroWings may be interested in charter flights linked with the nearby Felix resort on the mountain edge.

Although the European Commission believes that small airports do not generally compete with others (except in some cases with neighbouring airports of similar size have overlapping market areas), it is evident that low-cost carriers may rely on small airports close to large ones and this provides a basis for competition between Arad and Timişoara (Fruhling 2006, p. 101); even though Wizz Air transferred to Cluj-Napoca, despite the improved facilities provided at Târgu Mureş in 2005.

However, Arad and Timişoara can together claim an advantage over the competition from Hungary and Serbia as the core of the dynamic West Region which has attracted heavy investment from Germany and Italy especially. With an urban population approaching half a million, the area offers both a relatively well-qualified workforce and a substantial local market, while costs are relatively low in Romania: labour, raw materials and energy as well as taxation (W ASSING 2008).

With good connections between Timişoara and Belgrade/Budapest/Szeged and between Oradea and Budapest/Debrecen, cross-border movement to airports will move in both directions and will not necessarily favour Romania. And while Timişoara has done well with its West European traffic as Carpatair's hub, it can be outflanked by the greater choice available to passengers, who begin their journey west with road travel to Belgrade or Budapest. Thus, the 'Paralela 45' travel agency runs buses (five hour journey) from Timişoara to Ferihégy to take advantage of direct flights to Western Europe that are not available at Timişoara. Meanwhile, direct flights from Belgrade to New York and Chicago attract bookings from Serbs (and others) living in Romanian Banat. But on the other hand many passengers from Szeged come to Timişoara for flights to Milan and Rome, while passengers from Debrecen travel to Oradea for flights to Italy and Moldavia; although the flow is in the opposite direction for Debrecen's low cost flights to Dresden and Leipzig/Halle. 
As more airports operate internationally (and Serbia becomes an EU member) the choices will increase and partnerships may well occur as the director of Timişoara airport has already acknowledged. Hence, the logic of closer collaboration between Timişoara, Arad and Oradea with local flights to take advantage of complementary programmes using buses or feeder air services. This line of thinking is clearly in the mind of the present Romanian Transport Minister Radu Berceanu, who proposed a unified Banat Airport combining Arad and Timişoara into one unit.

The idea of an integrated Banat airport was mooted in 2008 and formally announced in 2009 as the brainchild of the Liberal-Democrat Party (PD-L), given the party's position in Arad Town Hall (Mayor FALCĂ) and the Transport Ministry. However, it will not be a union of equals, since Arad has a freight service but only one passenger flight daily (76,000 passengers in 2008), while Timişoara with 40-50 flights daily is getting close of a million passengers in a year.

Timişoara's Mayor CiUHANDu has therefore expressed opposition, while likening the deal to a union between an elephant and a flea. Moreover, Timişoara is profitable while Arad has debts. Naturally PD-L wants a solution that will help Arad - with promises to the mayor through party channels - while making sense for the longer term. But for Timişoara it is less satisfactory, since the airport is in a strong position and any concentration on cargo at Arad would undermine local development of airport-related industry in the city. Also shouldering Arad's debts could constrain Timişoara's plans for expansion.

Yet, while Arad is already in local government hands, the government still owns the airport at Timişoara and, especially since the business is profitable, it is not obliged to transfer ownership to a local organisation unless the terms are acceptable. CiuHANDU has suggested a joint effort at Ortişoara (a military airport unused since Romania joined NATO), but this is not acceptable to Arad.

So, while the merger seems an attractive option in the long-term, it is controversial in being much more to Arad's advantage than Timişoara's, while political party divisions heighten sensitivities; although on this score the government's defeat in late 2009 has created a new situation. However, the issue is something of a test case since amalgamation is conceivable in other areas, e.g. Baia Mare/Satu Mare; not to mention possible developments in Moldavia and Transylvania, but there is no state ownership involved for the state to exploit.

\section{Conclusion}

Air traffic is increasing rapidly in Romania after almost a century of activity since the first experiments were conducted shortly before the First World War. Thanks to the stimulus provided by low-cost carriers air travel has expanded faster than the country's overall economic growth would suggest. The role of the state has always been substantial in Romania, and the state monopoly maintained under Communism 
did not require any significant nationalisation, but rather the complete rebuilding of war-damaged installations.

However, the competitive ethos of the EU is now securing a level playing field for private airlines to challenge the established 'flag carriers'. In this context Romania has spawned an interesting range of new projects, each of which has sought its own 'niche' in the market with encouraging results during the post-2000 years of sustained economic growth. Indeed, at one stage the Romanian 'flag carrier' was poised to withdraw from internal flights but had the re-enter the market when the private operator failed.

Air passengers in Romania increased by 5.49 millions in 2008 over 2005, encouraged by growing capacity nationally and regionally and affordable fares offered by the low-cost carriers. Airport development has also been impressive, with expansion in the capital is being matched by the leading regional airports which have ambitious plans to develop as integral parts of their respective cities and regional centres. And at the same time cross-border movements are creating an even more complex picture of a highly competitive business.

Thus, Romanian low-cost carriers are now engaged in a rapidly-expanding business that western companies are keen to contest as the new EU member states are seen as a new frontier. In this endeavour, the airlines will become increasing locked in combat as alliances are forged with an expanding airport network reflecting the ambitions of the country's emerging regional centres.

\section{Bibliography}

Agenţia pentru Dezvoltare Economică (ADETIM) (ed.) (2006), Investor's guide: Timiş County, Romania. Timişoara.

Agențille de Dezvoltare Economico-Socială (ADES) (ed.) (1998), Ghidul Investitorului 1998: Regiunea Economică Vest [Investment guide 1998: Economic region West]. Timişoara.

Alexa C. (2001), Transporturi şi expediţii internaţional [International transport and shipment]. Bucureşti, Editura ASE

Belgrade City Council (ed.) (2008), City of Belgrade Development Strategy. Goals, Concept and Strategic Priorities of Sustainable Development. Belgrade. - http://www.beograd. rs/download.php/documents//development_strategy.pdf

Burghouwt G. (2005), Airline network development in Europe and its implications for airport planning. Utrecht, Univ. of Utrecht, Faculty of Geosciences.

Burghouwt G., Hakoort J., Ritsema van Eck J. (2003), The spatial configuration of airline networks in Europe. In: Journal of Air Transport Management, 9, pp. 309-323.

Dempsey P.S. (2004), European aviation law. Den Haag, Kluwer Law Intern.

DobruszKes F. (2009), New Europe, new low-cost air services. In: Journal of Transport Geography, 17, 6, pp. 423-432.

Dumitrescu S., Bal A. (2002), Economia mondiale [Global economy]. Bucharest, Ed. Economică.

European Communities (ed.) (2007), Statistics in focus: air passenger transport in Europe in 2006. Luxembourg, Office for Official Publications of the European Communities. 
Eurostat (ed.) (2006), Air transport in Europe in 2004 - Statistics in focus. - http://epp.eurostat. ec.europa.eu/cache/ITY_OFFPUB/KS-NZ-06-002/EN/KS-NZ-06-002-EN.pdf

Francis G., Fidato A, Humphreys I. (2003), Airport-airline interaction: the impact of low-cost carriers on two European airports. In: Journal of Air Transport Management, 9, 4, pp. 267-273.

Fruhling P. (2006), The new European Commission's guidelines on aid to airports and aid by airports to airlines. In: Air \& Space Law, 31, 2, pp. 98-119.

Government of Romania (ed.) (2006), Sectoral operational programme - Transport (SOPT) 2007-2013. - http://www.mt.to/engleza/strategii/post/POS\%20Transport\%20final\%20 12\%20aprilie\%202006\%20MFP\%20-\%20MTCT.pdf

Graham A., Dennis N. (2006), Airport traffic and financial performance: a UK and Ireland case study. London, Univ. of Westminster.

Graham B.J. (1995), Geography and air transport. Chichester, John Wiley \& Sons.

Iordănescu D., Georgescu D. (1986), Construcţii pentru transporturi în România [Construction for transport in Romania]. 2 vol. Bucharest, Centrala de Construcţii Căile Ferate.

Kangis P., O'Reilly M.D. (2003), Strategies in a dynamic marketplace: a case study in the airline industry. In: Journal of Business Research, 56, 2, pp. 105-111.

KIss L. (2007), The changing traffic system of the South Great Plain. In: Kovács C. (ed.), From villages to cyberspace: in commemoration of the $65^{\text {th }}$ birthday of Rezsó Mészáros, pp. 83-93, Szeged, Univ. of Szeged, Depart. of Economic and Human Geography.

KurKó I. (2007), Regional Economic Development and Disparities in Romania. In: CERS, Technical University of Košice, Faculty of Economics (ed.), The $2^{\text {nd }}$ Central European Conf. in Regional Science, pp. 527-531. - http://www.cers.tuke.sk/cers2007/PDF/ Kurko.pdf

Loo B.P.Y. (2008), Passengers' airport choice within multi-airport regions (MAR): some insights from a stated preference survey at Hong Kong International Airport. In: Journal of Transport Geography, 16, pp. 117-125.

Madas M., Zografos K. (2008), Airport capacity versus demand: mismatch or mismanagement? In: Transportation Research, 42A, pp. 203-206.

Megginson Technologies Ltd. (ed.), Our airports. - http://www.ourairports.com/countries/RS (last access 28/10/2009)

MiHĂILESCU N. (1971), Aeroportul internaţional Bucureşti-Otopeni: prima poartă aeriană a României [International airport Bucharest-Otopeni: first entrance by air to Romania]. In: Terra, 3, 1, pp. 61-65.

Ministry of Economy and Transport (ed.) (2006), Transport Infrastructure Development in Hungary. Budapest.

Pavel S. (2004), Urban and rural spaces of Western Romania: transformations and evolutions. In: Geographica Timisiensis, 13, 1, pp. 83-93.

Pop G.P. (1984), România: geografie circulaţiei [Romania: transportation geography]. Bucharest, Ed. Ştiinţifică şi Enciclopedică.

RPB Netherlands Institute for Spatial Research (ed.) (2005), Verkenning Regionale Luchthavens. Rotterdam, NAI Uitgevers.

Rusta Z., Bugă D. (1984), Transporturile aeriene [Air transport]. In: CUCU V., Iordan I. (eds.), Geografia României: geografia umană-economică, pp. 442-446, Bucharest, Ed. Academiei RSR.

Sosna B., LuCAS R. (2007), Airports in Poland - a $€ 1.2$ bn business opportunity (= Polish Construction Review, Publ. PMR). 
W ASsing M.A. (2008), Central Europe: ready for take off? De invloed van decentrale overheden op de ontwikkeling van regionale luchthavens in Centraal-Europa en de bijdrage van deze luchthavens aan de regionale ontwikkeling aldaar - casestudie in een Hongaarse en een Roemeense grensregio [Central Europe: ready for take off? The influence of decentralised governments on the development of regional airports in Central Europe and the contribution of these airports to regional development - A case study of the Hungarian and Romanian border region]. Utrecht, Univ. Utrecht, Faculteit Geowetenschappen, Master Thesis. 